\title{
Włodzimierz Borodziej
}

Instytut Historyczny Uniwersytetu Warszawskiego

\section{Maciej Górny}

Instytut Historii im. T. Manteuffla PAN

\section{Piotr Tadeusz Kwiatkowski}

Uniwersytet SWPS, Warszawa

\section{Znaki niepodległości. Święto 11 Listopada w Polsce i jego odpowiedniki w międzywojennej Europie Środkowo-Wschodniej}

Zarys treści: Artykuł omawia polityki pamięci państw Europy Środkowo-Wschodniej w dwudziestoleciu międzywojennym w czterech obszarach. Pierwszy dotyczy sporów wokół daty uzyskania (albo odzyskania) niepodległości, względnie zjednoczenia kraju. Kolejny - pomników usuwanych i erygowanych po $1918 \mathrm{r}$. Trzeci przybliża losy grobów wojennych i upamiętnień poległych w I wojnie światowej i w walkach o niepodległość i granice. Ostatni analizuje okoliczności i symbolikę grobów nieznanego żołnierza.

The content outline: The article presents policies of memory pursued in the interwar period by the states of Central and Eastern Europe, on the basis of four groups of examples. The first one concerns controversies around the date of gaining (or regaining) independence, or unification of the country. The next one - monuments removed or erected after 1918. The third group focuses on the fate of war graves and commemoration places of people killed during the Great War and in fights for independence and frontiers, while the last one analyses the circumstances and symbolism of unknown soldiers' graves.

Słowa kluczowe: Święto Niepodległości, obchody rocznicowe, Europa Środkowo-Wschodnia, weterani, groby wojenne, groby nieznanego żołnierza, polityka pamięci

Keywords: National Independence Day, anniversary celebrations, Central and Eastern Europe, veterans, war graves, unknown soldiers' graves, policy of memory

I wojnę światową w Europie Środkowo-Wschodniej rozpętały wprawdzie imperia, ale żadne z nich jej nie przetrwało. Skutki kataklizmu - śmierć lub kalectwo milionów młodych mężczyzn, zniszczenia, głód, nędza i epidemie szalejące wśród 
osłabionej i niedożywionej ludności - dotknęły już zupełnie inne państwa. Nawet te, które w wyniku wojny jedynie zmieniły swoje granice, znacząco je powiększając (jak Serbia, następnie Królestwo Serbów, Chorwatów i Słoweńców) i Rumunia, albo zawężając (jak Węgry i Bułgaria), wyszły z wojny zupełnie odmienione. Integracja wewnętrzna wszystkich tych państw była zadaniem trudnym, najczęściej zbyt trudnym dla ich politycznych elit. Jej opis, nawet skrótowy, przekracza zresztą ramy artykułu. Skupimy się w nim tylko na jednym z pól, na których owa integracja się dokonywała: na pamięci o najjaśniejszym momencie w najnowszej historii owych państwowości - o symbolicznym początku niepodległości bądź zjednoczenia kraju. Wykształcające się w okresie międzywojennym rytuały i znaki symbolizujące nowy początek stanowiły trzon polityki historycznej państw regionu. Spojrzenie na niektóre ich aspekty pozwala także dostrzec grupy i wątki pomijane i marginalizowane, narracje sprzeczne z dominującymi, otwarte konflikty, wreszcie paralelny do oficjalnego proces powstawania znaków i rytuałów niepodległości niespełnionych i spraw przegranych ${ }^{1}$.

\section{Polskie spory o datę odzyskania niepodległości}

Wśród podstawowych symboli konstytuujących tożsamość państwowości musiało się znaleźć także nowe, republikańskie święto symbolizujące odzyskanie niepodległości. Problem w tym, że odrodzenie Polski było trwającym kilka lat procesem, na którego szczęśliwy finał złożyły się walki zbrojne i działania polityczne podejmowane przez różne środowiska, organizacje i formacje wojskowe w złożonym kontekście międzynarodowym. Trudno było wskazać konkretny fakt, który bezspornie uznać można za akt odzyskania niepodległości. Przyznawał to sam Józef Piłsudski, analizujący „trudności oznaczenia daty, kiedy Rzeczpospolita Polska, jako ustrój państwowy, mogła o sobie powiedzieć: jestem!"”2. Przez wiele lat toczyły się spory, w trakcie których większe lub mniejsze środowiska brały pod uwagę kilkanaście dat ${ }^{3} \mathrm{z}$ okresu znacznie dłuższego niż wyznaczony przez Piłsudskiego czas „między końcem października a końcem listopada” 1918 r. W tym współzawodnictwie brali udział proniemieccy i proaustriaccy konserwatyści, zwolennicy Marszałka, endecy, a także socjaliści.

${ }^{1}$ Artykuł niniejszy powstał na kanwie naszej pracy nad książką poświęconą Świętu Niepodległości w kontekście regionalnym od 1918 r. do dnia dzisiejszego. Praca ukaże się nakładem Międzynarodowego Centrum Kultury.

2 J. Piłsudski, Pierwsze dni Rzeczypospolitej Polskiej (wykład 1), w: tenże, Pisma zbiorowe, t. 8, red. K. Świtalski, Warszawa 1937, http://jpilsudski.org/artykuly-historyczne-pilsudski/ jozefa-pilsudskiego-pisma-zebrane/item/2245-pierwsze-dni-rzeczypospolitej-polskiej-wyklad-i (4 IV 2018).

${ }^{3}$ B. Wachowska, Od 11 listopada do 11 listopada czyli spory o symboliczne Święto Niepodległości Polski, „Acta Universitatis Lodziensis. Folia Historica” 54, 1995, s. 4-16. 
Pierwsza z ważnych dat to 16 sierpnia 1914 r., powstanie w Krakowie Naczelnego Komitetu Narodowego, stworzonego w wyniku porozumienia polskich środowisk konserwatywnych i demokratycznych proaustriackiego organu władzy wojskowej, politycznej i skarbowej dla Polaków mieszkających na terenie Galicji. Z inicjatywy NKN powołano 27 sierpnia 1914 r. Legiony Polskie, oddziały formalnie wchodzące $w$ skład sił zbrojnych monarchii austro-węgierskiej. Kolejna data to wycofanie się wojsk rosyjskich z Warszawy (5 sierpnia 1915 r.), które zbiegło się z rocznicą stracenia w 1864 r. na stokach Cytadeli warszawskiej członków Rządu Narodowego w powstaniu styczniowym. W pierwszą rocznicę tego wydarzenia zorganizowano w Warszawie uroczystość patriotyczną, w trakcie której ustawiono okazały dębowy krzyż z koroną cierniową, a pod nim umieszczono granitowy głaz z wyrytymi nazwiskami bohaterów. W czasie uroczystości przemawiał Ignacy Daszyński, który o przywódcach powstania styczniowego mówił „jako o duchowych i ideowych poprzednikach czynu legionowego"4. Kolejną datą, która kandydowała do rangi dnia niepodległości, był 5 listopada ${ }^{5}$. W ogłoszonej tego dnia proklamacji generalni gubernatorzy Hans Hartwig von Beseler i Karl Kuk zadeklarowali w imieniu swoich monarchów powstanie „samodzielnego" (nie użyto wyrazu „niepodległego”) Królestwa Polskiego, pozostającego „w łączności z obu sprzymierzonymi mocarstwami” i dysponującego wojskiem, w którym „nadal żyć będą pełne sławy tradycje wojsk polskich dawniejszych czasów i pamięć walecznych polskich towarzyszy broni w wielkiej obecnej wojnie"6. Czwartą rozważaną datą był 15 stycznia 1917 r., dzień inauguracyjnego posiedzenia Tymczasowej Rady Stanu, instytucji powołanej w grudniu 1916 r. przez niemieckie i austro-węgierskie władze okupacyjne w Królestwie Polskim jako realizacja obietnic zawartych w Akcie 5 listopada, ale przeciw obu tym datom przemawiała późniejsza historia Legionów Polskich.

W wyniku Aktu 5 listopada utworzono polskie instytucje (Tymczasową Radę Stanu, Radę Regencyjną) i wojsko, co zdaniem niektórych konserwatywnych historyków oznaczało, że - jak pisał Michał Bobrzyński - „po stu przeszło latach

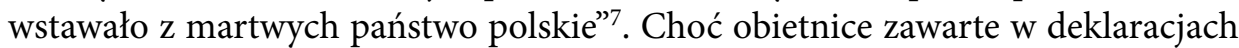
cesarzy były mgliste, a granice przyszłego państwa nieokreślone, poza tym nie ufano w dobre intencje administracji niemieckiej formującej polskie oddziały, to jednak faktem jest, że władcy Niemiec i Austro-Węgier uznali prawo Polaków do samodzielnego bytu państwowego i nadali sprawie polskiej charakter międzynarodowy.

${ }^{4}$ J. Rusin, Legenda Traugutta i jubileusze. Wybrane przykłady, „Prace Naukowe Akademii im. Jana Długosza w Częstochowie. Filologia Polska. Historia i Teoria Literatury" 13, 2013, s. 74.

5 Z. Gnat-Wieteska, Akt 5 listopada, jego postanowienia i znaczenie, „Niepodległość i Pamięć” 23, 2016, nr 2(54), s. 15.

${ }^{6}$ Cyt. z Aktu 5 listopada za: tamże.

${ }^{7}$ M. Bobrzyński, Wskrzeszenie państwa polskiego. Szkic historyczny, t. 1, Kraków 1920, s. 115. 
Inaczej wydarzenia interpretował Roman Dmowski, który Akt 5 listopada i następujące po nim decyzje postrzegał jako cyniczną niemiecką grę nastawioną na pozyskanie nowych „rekrutów” oraz próbę rozszerzenia i stabilizacji strefy wpływów w Europie Środkowej: „Niemcy liczyli, że w razie nawet przegranej na froncie uda im się osiągnąć zwycięstwo polityczne, urzeczywistnić swój główny cel - niepodzielne zapanowanie w Europie Środkowej. Nowe Królestwo Polskie pozostałoby jako jedna z części składowych niemieckiego systemu Europy Środkowej (Mitteleuropa) i nie miałoby żadnych widoków wyłamania się spod władzy niemieckiej"s.

Następne ważne daty w procesie odbudowy niepodległego państwa wiążą się z aktywnością wspomnianej już Rady Regencyjnej, powołanej 12 września 1917 r. na mocy patentu podpisanego przez gubernatorów generalnych Stanisława Szeptyckiego i Beselera ${ }^{9}$. Rada istniała rok i 19 dni, w tym czasie działała „w imieniu państwowości polskiej i na jej rzecz"10: wydała wiele aktów, które dały początek systemowi prawnemu II Rzeczypospolitej, ogłaszała te akty w systematycznie wydawanym Dzienniku Praw Królestwa Polskiego ${ }^{11}$, organizowała administrację państwową i system oświaty, wysłała za granicę pierwszych przedstawicieli (quasi)-dyplomatycznych (którzy siłą rzeczy natychmiast popadali w konflikty z miejscowymi wysłannikami Komitetu Narodowego Polskiego) ${ }^{12}$, powołała Główny Urząd Statystyczny, przygotowała rozwiązania prawne niezbędne do zorganizowania Wojska Polskiego, wypowiadała się też w istotnych dla Polski kwestiach polityki międzynarodowej ${ }^{13}$. Dlatego, zdaniem niektórych prawników, z formalnego punktu widzenia odrodzenie polskiej państwowej władzy najwyższej nastąpiło już na początku 1918 r. ${ }^{14} 7$ października 1918 r. ogłoszone zostało Orę-

${ }^{8}$ R. Dmowski, Pisma, t. 5: Polityka polska i odbudowanie państwa, cz. 1: Przed wojna; Wojna r. 1917, Częstochowa 1937, s. 349.

${ }^{9}$ Patent z 12 IX 1917 r. o ustanowieniu władzy państwowej w Królestwie Polskim, Dziennik Urzędowy Departamentu Sprawiedliwości Tymczasowej Rady Stanu Królestwa Polskiego, nr 5, Warszawa, 2 X 1917 r., http://pbc.biaman.pl/Content/24146/Dziennik\%205.pdf (4 IV 2018).

10 J. Winnicki, Rada Regencyjna Królestwa Polskiego i jej organy 1917-1918, Wrocław 2007, s. 331 .

11 Dziennik Ustaw, utworzony na mocy art. 21 Dekretu Rady Regencyjnej z 3 I 1918 r. o tymczasowej organizacji władz naczelnych w Królestwie Polskiem, Dziennik Praw Królestwa Polskiego, 1918, nr 1, poz. 1. Od 8 XI 1918 r. publikowany pt. Dziennik Praw Państwa Polskiego, a od 1919 r. do chwili obecnej jako Dziennik Ustaw na mocy Ustawy z 31 VII 1919 r. w sprawie wydawania Dziennika Ustaw Rzeczypospolitej Polskiej, Dziennik Ustaw, 1919, nr 66, poz. 400 oraz Dziennik Ustaw, 1925, nr 1, poz. 1.

12 Obszerną dokumentację tego tematu przestawił ostatnio S. Dębski; zob. Polskie dokumenty dyplomatyczne, styczeń-maj 1919 r., red. S. Dębski, Warszawa 2017.

${ }_{13}$ J. Mierzwa, Dorobek Tymczasowej Rady Stanu i Rady Regencyjnej w budowie aparatu administracyjnego Polski Niepodległej, w: Akt 5 listopada i jego konsekwencje dla Polski i Europy, red. J. Kłaczkow, K. Kania, Z. Girzyński, Toruń 2016, s. 151-156.

${ }^{14}$ L. Antonowicz, Narodziny Drugiej Rzeczypospolitej ze stanowiska prawa międzynarodowego, „Przegląd Sejmowy” 1998, nr 5(28), s. 17-22. 
dzie Rady Regencyjnej do Narodu Polskiego zapowiadające niepodległość Polski i powołujące się na program pokojowy, który prezydent Stanów Zjednoczonych Thomas Woodrow Wilson przedstawił w swoim orędziu do Kongresu 8 stycznia 1918 r., a zaakceptowany on został 5 października 1918 r. przez kanclerza Rzeszy Maxa von Badena jako podstawa do rokowań pokojowych. Punkt trzynasty dokumentu, określanego jako „14 punktów Wilsona”, mówił o utworzeniu niepodległego państwa polskiego $\mathrm{z}$ dostępem do morza na terenach zamieszkanych w większości przez ludność polską. Rada Regencyjna zareagowała nań, stwierdzając: „W stosunku do Polski zasady te prowadzą do utworzenia niepodległego państwa, obejmującego wszystkie ziemie polskie, $\mathrm{z}$ dostępem do morza, z polityczną i gospodarczą niezawisłością, jako też z terytorialną nienaruszalnością, co przez traktaty międzynarodowe zagwarantowanem będzie"15. 12 października Rada Regencyjna przejęła $\mathrm{z}$ rąk generalnego gubernatora Beselera władzę zwierzchnią nad wojskiem, a 21 października niemiecki generał-gubernator warszawski oficjalnie przekazał władzom polskim dowództwo nad oddziałami. Dwa dni później Rada powołała rząd Józefa Świeżyńskiego, ostatni w Królestwie Polskim, ale pierwszy utworzony bez porozumienia z przedstawicielami władz państw zaborczych.

Na terenie ziem byłego zaboru austriackiego za dzień odrodzenia Polski wielu uważało (i uważa do dziś) 31 października 1918 r., datę obalenia panowania austriackiego i objęcia władzy w Krakowie, a następnie w innych miastach zachodniej Galicji przez Polską Komisję Likwidacyjną, w pełni suwerenny ośrodek polskiej władzy. Przewodniczący Komisji, Wincenty Witos wspominał: „W Krakowie bardzo szybko pozbywano się wszystkiego, co trąciło niemczyzną i przypominało austriackie panowanie. [...] panował nastrój podniosły i świąteczny, nie zmącony żadnym wykroczeniem" 16 .

W roku dziesięciolecia odzyskania niepodległości „Ilustrowany Kurier Codzienny", dziennik polityczno-informacyjny wydawany w latach 1910-1939 w Krakowie, opublikował tekst pod znamiennym tytułem Nie traćmy historycznej pamięci!, w którym autor apelował o świętowanie „prawdziwej” daty odzyskania niepodległości, twierdząc, że „dzień 31 października, insurekcji krakowskiej jest faktycznie i istotnie pierwszym, historycznym dniem niepodległości państwowej Polski i już jako taki, powinien być uroczyście obchodzony"17. W innych regionach nie podzielano tego poglądu, Piłsudski zaś twierdził, że komisja powstała w wyniku rozpadu byłego państwa zaborczego, działała na terenie jednego zaboru i miała charakter instytucji tymczasowej: „Nazwa wynikła z tego, że »Komisja Likwidacyjna" rozpoczęła swoje istnienie i swoją pracę na podstawie aktu nie

15 Orędzie Rady Regencyjnej do Narodu Polskiego, 21 X 1918 r., Dziennik Praw Królestwa Polskiego, nr 12, poz. 23, http://dziennikustaw.gov.pl/DU/1918/23 (4 IV 2018).

16 W. Witos, Moje wspomnienia, oprac. A. Czubiński, Z. Hammerling, S. Lato, W. Stankiewicz, Warszawa 1981, s. 536.

${ }^{17}$ Nie traćmy historycznej pamięci!, „Ilustrowany Kurier Codzienny” 5 XI 1928, s. 3. 
swojego, ale obcego, zaborczego państwa, na podstawie aktu cesarza Karola, który rozwiązał niejako Austrię, oparta na tym akcie »Komisja Likwidacyjna« zaczęła rządzić tą częścią Polski, która była związana z Krakowem. Dlatego nazwała się w tak dziwaczny sposób »Komisją Likwidacyjną» - likwidującą stan zaboru i nie mającą właściwie charakteru rządzenia"18.

Dla zwolenników lewicy symbolem niepodległości stało się utworzenie w Lublinie 7 listopada 1918 r. Tymczasowego Rządu Republiki Polskiej z Ignacym Daszyńskim na czele ${ }^{19}$. Gabinet nazywany lubelskim miał zaplecze polityczne ograniczone do lewicy niepodległościowej, działał krótko - do 11 listopada, ale stanowił istotny epizod w kształtowaniu się niepodległego państwa, ponieważ sformułował program polityczny zawierający wiele postulatów ważnych w całym dwudziestoleciu międzywojennym. Znalazły się w nim zasady równości praw wszystkich obywateli bez względu na pochodzenie społeczne, narodowość i wyznanie, a także wolności sumienia, słowa, zgromadzeń i zrzeszania się. Radykalne były pomysły tego gabinetu w zakresie prawa do własności środków produkcji - zapowiadano m.in. reformę rolną i nacjonalizację dużych przedsiębiorstw oraz niektórych gałęzi gospodarki.

Kolejne daty, które można było uznać za symboliczny początek niepodległej Rzeczypospolitej, związane są z przybyciem 10 listopada do Warszawy Józefa Piłsudskiego. Przyjechał on po zwolnieniu z więzienia w Magdeburgu, gdy, jak to później określił: „Godziny na zegarze dziejowym spieszyły, biły szybko jedna za drugą, jak gdyby wymagały od Polaków, aby szli w takt bicia zegaru, gdy godzina do godziny stawała się niepodobną ${ }^{20}$. Następnego dnia, w poniedziałek 11 listopada 1918 r., gdy w Compiègne podpisano układ rozejmowy kończący I wojnę światową, w Warszawie Rada Regencyjna przekazała „władzę wojskową i naczelne dowództwo wojsk jej podległych Brygadjerowi Józefowi Piłsudskiemu"21. 14 listopada zaś „znikła najpoważniejsza monarchistyczna instytucja na ziemiach polskich”22, a jej członkowie oświadczyli: „postanawiamy Radę Regencyjną rozwiązać, a od tej chwili obowiązki nasze i odpowiedzialność względem narodu polskiego w Twoje ręce, Panie Naczelny Dowódco składamy”23. Data przejęcia pełni władzy przez

18 J. Piłsudski, dz. cyt.

19 C. Brzoza, A.L. Sowa, Historia Polski 1918-1945, Kraków 2006, s. 21-22.

${ }^{20}$ J. Piłsudski, Pierwsze dni Rzeczypospolitej Polskiej (wykład 2), w: tenże, Pisma zbiorowe..., t. 8, http://www.jpilsudski.org/artykuly-historyczne-pilsudski/jozefa-pilsudskiego-pisma-zebrane/ item/2246-jozef-pilsudski-pierwsze-dni-rzeczypospolitej-polskiej-wyklad-drugi (4 VI 2017).

${ }^{21}$ Orędzie Rady Regencyjnej w przedmiocie przekazania naczelnego dowództwa wojsk polskich brygadjerowi Józefowi Piłsudskiemu, 11 XI 1918 r., Dziennik Praw Państwa Polskiego, 1918, nr 17 poz. 38, http://isap.sejm.gov.pl/DetailsServlet?id=WDU19180170038 (4 VI 2017).

22 C. Brzoza, A.L. Sowa, dz. cyt., s. 58.

${ }^{23}$ Orędzie Rady Regencyjnej w przedmiocie rozwiązania Rady Regencyjnej i przekazania Najwyższej Władzy Państwowej naczelnemu dowódcy wojsk polskich Józefowi Piłsudskiemu, 14 XI 1918 r., Praw Państwa Polskiego, 1918, nr 17, poz. 39, http://isap.sejm.gov.pl/DetailsServlet?i$\mathrm{d}=$ WDU19180170039 (4 IV 2018). 
Komendanta $\mathrm{w}$ okresie międzywojennym pojawiała się $\mathrm{w}$ propagandzie środowisk piłsudczykowskich, a uroczystość wręczenia „brygadierowi” buławy marszałkowskiej odbyła się dokładnie dwa lata później, 14 listopada $1920 \mathrm{r}^{24} 16$ listopada Piłsudski jako Wódz Naczelny przesłał rządom Stanów Zjednoczonych, Wielkiej Brytanii, Francji, Włoch, Japonii, Niemiec oraz „wszystkich Państw wojujących i neutralnych" depeszę, w której obwieszczał fakt powstania niepodległego państwa polskiego $^{25}$. Piłsudski sprawował władzę na podstawie decyzji Rady Regencyjnej do czasu wydania dekretu z 22 listopada 1918 r. (opublikowanego i wchodzącego w życie tydzień później) „o najwyższej władzy reprezentacyjnej Republiki Polskiej”26, a 28 listopada 1918 r., na podstawie projektu opracowanego przez rząd Jędrzeja Moraczewskiego, wydał dekret o ordynacji wyborczej do Sejmu Ustawodawczego ${ }^{27}$. Po latach te dwie daty Piłsudski był skłonny uznawać za początek funkcjonowania niepodległego państwa ${ }^{28}$. Do długiej listy dat pretendujących do rangi symbolu wskrzeszenia państwa polskiego dopisać trzeba też 10 lutego 1919 r. - otwarcie Sejmu Ustawodawczego. Naczelnik Państwa, aby „uczcić i upamiętnić wielki dla Narodu Polskiego dzień" uznał go za jednorazowe święto narodowe ${ }^{29}$, a podczas uroczystości otwarcia Sejmu mówił: „W tej godzinie wielkiego serc polskich bicia czuję się szczęśliwym, że przypadł mi zaszczyt otwierać Sejm polski, który znowu będzie domu swego ojczystego jedynym panem i gospodarzem" ${ }^{30}$.

Jako początek niepodległego bytu państwowego niektórzy szczególnie zagorzali zwolennicy Marszałka uważali uchwalenie przez Sejm Ustawodawczy uchwały z 20 lutego 1919 r. „W sprawie powierzenia Józefowi Piłsudskiemu dalszego sprawowania urzędu Naczelnika Państwa"31, zwanej małą konstytucją i określającej

24 B. Wachowska, dz. cyt., s. 14.

25 Depesza Wodza Naczelnego z 16 XI 1918 r. notyfikująca powstanie niepodległego państwa polskiego, Monitor Polski. Dziennik Urzędowy Republiki Polskiej, rok I, nr 206, 18 XI 1918 r., s. 1, http://buwcd.buw.uw.edu.pl/e_zbiory/ckcp/monitor_pl/1918-11/11-206/index.htm (4 IV 2018).

${ }^{26}$ Dekret Naczelnika Państwa z 22 XI 1918 r. o najwyższej władzy reprezentacyjnej Republiki Polskiej, 29 XI 1918 r., Dziennik Praw Państwa Polskiego, 1918, nr 17, poz. 41, http://isap.sejm.gov. pl/DetailsServlet?id=WDU19180170041 (4 IV 2018).

27 Dekret o ordynacji wyborczej do Sejmu Ustawodawczego z 28 XI 1918 r., Dziennik Praw Państwa Polskiego, 1918, nr 18, poz. 46, http://isap.sejm.gov.pl/DetailsServlet?id=WDU19180180046 (4 VI 2017).

${ }^{28}$ A. Dobroński, Obchody święta niepodległości w II Rzeczypospolitej, w: Święto Niepodległości - tradycja a wspótczesność, red. A. Stawarz, Warszawa 2003, s. 10.

${ }^{29}$ Dekret o święcie narodowym z okazji otwarcia Sejmu Ustawodawczego, Dziennik Praw Państwa Polskiego, 1919, nr 16, poz. 218, http://dziennikustaw.gov.pl/du/1919/s/16/218 (4 IV 2018).

30 J. Piłsudski, Przemówienie na otwarcie Sejmu Ustawodawczego 10 lutego 1919 r., w: tenże, Pisma zbiorowe, t. 5, red. K. Świtalski, Warszawa 1937, s. 55-56, http://jpilsudski.org/artykuly-historyczne-pilsudski/jozefa-pilsudskiego-pisma-zebrane/item/2245-pierwsze-dni-rzeczypospolitejpolskiej-wyklad-i (4 IV 2018).

${ }^{31}$ Uchwała Sejmu Ustawodawczego z 20 II 1919 r. w sprawie powierzenia Józefowi Piłsudskiemu dalszego sprawowania urzędu Naczelnika Państwa, Dziennik Praw Państwa Polskiego, 1919, nr 19, poz. 226, http://isap.sejm.gov.pl/DetailsServlet?id=WDU19190190226 (4 IV 2018). 
system rządów w państwie. Zwolennicy narodowej demokracji podkreślali natomiast „zadanie zdobycia dla Polski miejsca wśród państw sprzymierzonych"32, międzynarodową rolę, jaką w latach 1917-1919 odegrał Komitet Narodowy Polski założony przez Romana Dmowskiego 17 sierpnia 1917 r., a jesienią tego roku uznany przez Francję, Wielką Brytanię, Włochy i Stany Zjednoczone za reprezentację odradzającej się Polski ${ }^{33}$. Zwolennicy tej orientacji politycznej eksponowali zatem znaczenie czynników międzynarodowych w odzyskaniu niepodległości przez Polskę, zwłaszcza poparcie Francji i USA, a za przełomowe wydarzenie uważali podpisanie traktatu pokojowego w Wersalu 28 czerwca $1919 \mathrm{r}^{34}$, które było faktem ustalającym nowy ład międzynarodowy, a z perspektywy Polaków stanowiło sukces kończący historyczną misję Komitetu Narodowego Polskiego.

Po latach sporów, ale też corocznych obchodów, które się zinstytucjonalizowały i stały częścią kultury politycznej, polskie władze wróciły do tematu prawnych regulacji związanych z rocznicą. Sejm, wybrany zgodnie z konstytucją kwietniową z 1935 r., która zmniejszyła liczbę posłów do 208 i wprowadziła antydemokratyczną procedurę zgłaszania i ustalania list kandydatów na posłów, zatwierdził ustawą z 23 kwietnia 1937 r. Święto Niepodległości: „Dzień 11 listopada, jako rocznica odzyskania przez Naród Polski niepodległego bytu państwowego i jako dzień po wsze czasy związany z wielkim imieniem Józefa Piłsudskiego, zwycięskiego Wodza Narodu w walkach o wolność Ojczyzny - jest uroczystym Świętem Niepodległości”35.

\section{Warianty niepodległości}

Kontrowersje dotyczące „dnia niepodległości” czy też „dnia zjednoczenia” nie były polską specyfiką. Jako takie przyjmowane były często daty nieoczywiste. W lutym 1918 r. litewska Taryba, namiastka parlamentu, ogłosiła deklarację niepodległości: „Rada Litewska jako jedyna przedstawicielka narodu litewskiego, opierając się na prawie narodów do samookreślenia [...] ogłasza odbudowę niepodległego, opartego na zasadach demokratycznych państwa litewskiego ze stolicą w Wilnie, jak również oddzielonego od wszystkich związków państwowych, które kiedykolwiek były z innymi narodami. Równocześnie Rada Litwy ogłasza, że fundamenty państwa litewskiego i jego stosunki z innymi krajami powinien określić jak najszybciej zwołany, w sposób demokratyczny przez mieszkańców wybrany, Sejm Ustawodawczy" ${ }^{\text {36 }}$.

32 R. Dmowski, Pisma, t. 6: Polityka polska i odbudowanie państwa, cz. 2: Wojna od r. 1917; Pokój, Częstochowa 1937, s. 27.

33 Tamże, s. 27-50.

34 B. Wachowska, dz. cyt., s. 15-16.

35 Ustawa z 23 IV 1937 r. o Święcie Niepodległości, Dziennik Ustaw Rzeczypospolitej Polskiej, 1937, nr 33, poz. 255, http://dziennikustaw.gov.pl/du/1937/s/33/255 (4 VI 2016).

36 A. Pukszto, Między stołecznościa a partykularyzmem. Wielonarodowościowe społeczeństwo Wilna w latach 1915-1920, Toruń 2006, s. 89. 
Tydzień później to samo uczyniła Estonia. I w jednym, i w drugim przypadku chodziło o działania w głównej mierze symboliczne. Wkraczająca do guberni bałtyckich armia niemiecka błyskawicznie przerwała byt tych nowych państwowości. Odrodziły się dopiero późną jesienią, kiedy wojska cesarskie pakowały się już do domu po przegranej wojnie. Niemniej w kalendarzu oficjalnym Litwy i Estonii niepodległość świętowano właśnie w lutym, nie zaś w listopadzie.

Także ustalenie momentu powstania państwa Czechów i Słowaków nie było sprawą prostą i jednoznaczną. František Soukup, jeden z pierwszoplanowych aktorów praskiego przewrotu w październiku 1918 r. i główny „brązownik” tych wydarzeń, pisał w opasłym rocznicowym dziele: „28 października 1918 roku to szczytowy dzień dotychczasowych dziejów narodu; tego dnia lud nasz zgodną wolą milionów proklamował Republikę Czechosłowacką, powołując na jej czoło Tomáša Garrigue Masaryka. Nie ma w naszej historii nic większego. Pod względem moralnej siły, podziwu godnej jedności przekonań! Gigantycznego wymiaru walki, heroicznej siły czynów! Determinacji za cenę każdej ofiary, by walczyć o wolność narodu, oraz zrozumienia roli wolności dla ludzkości”37.

Jednocześnie książka Soukupa dostarcza wielu konkurencyjnych opcji daty przełomu, zbieżnych z którymś z wielu etapów na drodze do pierwszego dnia wolności. Wymieńmy tylko te najważniejsze. 13 kwietnia 1918 r. obywatele zgromadzeni w Obecním domu w Pradze złożyli „rewolucyjną przysięgę”: „Nie chcemy życia bez wolności i niepodległości, pragniemy decydować o własnym losie poprzez własną władzę, wolni i bez ograniczeń budować swoją przyszłość, tak jak pragnie tego każdy świadomy naród w całym cywilizowanym świecie" ${ }^{\prime 3}$. 16 maja w tym samym miejscu oraz w budynku Muzeum Królestwa Czeskiego obradował zjazd „uciskanych narodów” Austro-Węgier. Towarzyszyły mu masowe demonstracje na praskich ulicach $\mathrm{z}$ hasłami narodowej niepodległości na sztandarach. 14 października socjaldemokraci zwołali strajk generalny, który tylko z największym trudem udało się władzom austriackim opanować z pomocą wojska. Dla czeskiej lewicy w okresie międzywojennym będzie to data bardziej znacząca niż 28 października. Wreszcie 18 października w Waszyngtonie Masaryk proklamował czeską niepodległość.

I to właśnie Masaryk osobiście dokonał ostatecznego wyboru daty narodowego święta Republiki Czechosłowackiej. Uznając, że realne przejęcie władzy w Pradze przez Komitet Narodowy ma największy ciężar symboliczny, podjął jednocześnie polityczną decyzję, która wcale nie wszystkim się spodobała ${ }^{39}$. Otóż 28 października dotyczył prawie wyłącznie Pragi, w nieco mniejszym stopniu pozostałych ziem

${ }^{37}$ F. Soukup, 28. Říjen. Předpoklady a vývoj našeho odboje domácího v československé resoluci za statní samostatnost národa, Praha 1928, s. 11, 14 (tłum. M. Górny).

38 Tamże, s. 657 (tłum. M. Górny).

39 T.G. Masaryk, Die Weltrevolution. Erinnerungen und Betrachtungen 1914-1918, Berlin 1925, s. 406. 
czeskich. W Bratysławie tymczasem, wówczas jeszcze madziarsko-niemieckim Pozsony, tego akurat dnia nic szczególnie ważnego się nie wydarzyło. Dopiero 30 października w Martinie (Turócszentmártonie) za zgodą węgierskich władz w budynku banku Tatra odbył się zjazd słowackich działaczy narodowych. W uchwalonej tam rezolucji zebrani domagali się dla Słowaków prawa do samostanowienia. Na tym się jednak nie skończyło. Już po głosowaniu, kiedy większość sygnatariuszy rozjechała się do domów, do Martina dotarł z Budapesztu Milan Hodža, przynosząc najnowsze wieści o kapitulacji Austro-Węgier. Pod wrażeniem tych rewelacji z deklaracji wykreślono niektóre passusy, np. żądanie dopuszczenia samodzielnej reprezentacji Słowaków na konferencję pokojową (uznano, że taki postulat w sytuacji, kiedy w Paryżu przebywała już delegacja czechosłowacka, byłby wotum nieufności wobec młodej republiki) ${ }^{40}$. Zarówno późniejsza data ogłoszenia słowackiej deklaracji, jak i ingerencje w jej treść już po tym fakcie dawały pożywkę krytyce czeskiego „imperializmu” i czasem zupełnie fantastycznym spekulacjom. Powiadano np., że ingerencje Hodžy tak bardzo zmieniły treść dokumentu, że odebrały mu jakiekolwiek znaczenie. Pojawiły się także uparte pogłoski o tajnym protokole, obiecującym Słowakom większy zakres politycznej samodzielności niż ten, który ostatecznie w nowym państwie otrzymali. Wątpliwości co do wydarzeń 30 października rykoszetem trafiały w święto czechosłowackiej niepodległości dla wielu Słowaków zawsze trochę obce.

Decyzja Masaryka wywołała sprzeciw także z innej strony. 28 października symbolizował krajowy opór przeciwko Habsburgom, oddając szacunek także tym aktorom życia publicznego, którzy (jak np. Soukup) na akty odwagi cywilnej zdecydowali się stosunkowo późno. Wcześniej pozostawali lojalnymi poddanymi monarchii. W oczach radykałów do miana prawdziwej rewolucji przewrotowi 28 października brakowało krwi, ognia i szubienic dla zdrajców. Wszystko to najbardziej irytowało środowisko uważające się za jedynych prawdziwych bohaterów narodowej rewolucji, czyli czechosłowackich legionistów. W prasie i w wystąpieniach publicznych wytrwale, przez całe dwudziestolecie, przypominali, że prawdziwi bohaterowie znajdowali się jesienią 1918 r. na Syberii, a nie w Pradze ${ }^{41}$.

Polityczne spory o prestiż związany z najważniejszym świętem młodego państwa, podobnie jak w Polsce, bywały symbolicznym odpowiednikiem politycznych programów. Widać to szczególnie wyraźnie na przykładzie Rumunii, gdzie 1 grudnia upamiętniano wprawdzie wielkie zgromadzenie w Alba Iulia i decyzje o zjednoczeniu Siedmiogrodu, Banatu, Crişany i Maramureş z Królestwem Rumunii, święta państwowe odnosiły się jednak do tradycji dynastycznej starego Królestwa.

${ }^{40}$ D. Kováč, 30. Október 1918 a jeho muži, w: Muži Deklarácie, Bratislava 2000, s. 13-14.

${ }^{41}$ N. Stegmann, „Geburt" und „Wiedererrichtung“ der Tschechoslowakei. Das Legionäsparadigma am Ende des Ersten und des Zweiten Weltkrieges, w: Die Weltkriege als symbolische Bezugspunkte. Polen, die Tschechoslowakei und Deutschland nach dem Ersten und Zweiten Weltkrieg, red. N. Stegmann, Praha 2009, s. 76. 
Z czasem dzień zjednoczenia nabrał opozycyjnych odcieni, stając się symbolem regionalnym, siedmiogrodzkim, skierowanym bardziej przeciw Bukaresztowi niż przeciw Budapesztowi ${ }^{42}$.

Podobnego charakteru nabrało nieoficjalne święto niepodległości Państwa Słoweńców, Chorwatów i Serbów, krótkotrwałej republiki, powołanej do życia w ostatnich dniach istnienia monarchii habsburskiej i połączonej z Serbią w Królestwo Serbów, Chorwatów i Słoweńców 1 grudnia 1918 r. W Chorwacji i Słowenii 29 października, dzień utworzenia Państwa SHS, był przez cały okres międzywojenny okazją do patriotycznych uroczystości, początkowo tylko łagodnie zaznaczających odrębność obu narodów od Serbii, ale z czasem coraz otwarciej opozycyjnych wobec belgradzkiego centralizmu ${ }^{43}$.

Nie tylko siedmiogrodzcy Rumuni i Chorwaci manifestowali swoje niezadowolenie przy okazji alternatywnych obchodów. Jeszcze więcej powodów do protestów miały mniejszości narodowe, czasami tak liczne, że na wielkich połaciach kraju stawały się dominującą większością. W Galicji Wschodniej polska polityka symboliczna wielokrotnie znajdowała się na kursie kolizyjnym z upamiętnieniami Zachodnioukraińskiej Republiki Ludowej, powołanej do życia 1 listopada 1918 r. Państwo polskie nie tolerowało poświęconych jej obchodów. Dopuszczało wyłącznie msze upamiętniające ukraińskie ofiary wojny 1919 r., czyli postępowało tak samo jak niegdyś rząd Prus wobec obchodów rocznicy uchwalenia Konstytucji 3 maja $^{44}$. Do eskalacji konfliktu doszło w 1928 r. Noca z 31 października na 1 listopada nieznani sprawcy uszkodzili pomnik Obrońców Lwowa na Persenkówce i pomnik Orląt na Politechnice. Na gmachach publicznych zawisły ukraińskie flagi, tak że miasto rzeczywiście przypominało widok sprzed dekady. 1 listopada doszło do strzelaniny pomiędzy młodymi ukraińskimi nacjonalistami i policją. W kolejnych dniach polscy nacjonaliści zdemolowali lokale kilku ukraińskich instytucji ${ }^{45}$. W następnych latach w rocznicę ustanowienia ukraińskiej republiki we Lwowie regularnie dochodziło do scysji polskich i ukraińskich studentów. Zdarzały się zamachy terrorystyczne, na porządku dziennym był jednak przede wszystkim wandalizm. Co jakiś czas wir polsko-ukraińskiego sporu wciągał stojących $\mathrm{z}$ boku obserwatorów, nieutożsamiających się ani $\mathrm{z}$ jedną, ani z drugą stroną - żydowską ludność Lwowa, bitą i okradaną przez endeckich studentów.

42 I. Livezeanu, Cultural Politics in Greater Romania. Regionalism, Nation Building and Ethnic Struggle, 1918-1930, Ithaca 2000, s. 130-133.

${ }^{43}$ P. Barišić, Gedenktage in Kroatien als Medium der Geschichtserzählung, w: Der Kampf um Gedächtnis. Öffentliche Gedenktage in Mitteleuropa, red. E. Brix, H. Steckl, Wien 1997, s. 353.

${ }^{44}$ C. Mick, The Dead and the Living. War Veterans and Memorial Culture in Interwar Polish Galicia, w: Sacrifice and Rebirth. The Legacy of the Last Habsburg War, red. M. Cornwall, J.P. Newman, Oxford 2016, s. 244.

${ }^{45}$ G. Mazur, Życie polityczne polskiego Lwowa 1918-1939, Kraków 2007, s. 123. 
Niemcy sudeccy, czyli najliczniejsza mniejszość etniczna Czechosłowacji, także dorobili się własnego święta, niedającego się w żaden sposób pogodzić z oficjalną polityką symboliczną państwa. Chodziło o upamiętnienie ofiar manifestacji z 4 marca 1919 r. Niemieccy manifestanci w Kadaňu i kilku innych miejscowościach, domagający się zarówno poprawy warunków pracy, jak i zezwolenia na udział w wyborach do austriackiego Zgromadzenia Narodowego, zostali wówczas ostrzelani przez czechosłowackie wojsko ${ }^{46}$. Doszło do zamieszek, było kilkadziesiąt ofiar śmiertelnych, a „marcowe ofiary” stały się mitem założycielskim nowej, sudecko-niemieckiej irredenty. Mimo zakazu, w kolejnych latach odbywały się uroczystości ku czci ofiar tych wypadków, a w 1925 r. dużą manifestację zorganizowano także poza granicami ČSR, pod wiedeńskim parlamentem ${ }^{47}$.

Bardzo podobny charakter miała obchodzona przez chorwackich opozycjonistów rocznica krwawych wydarzeń z 5 grudnia 1918 r. Na placu Jelačicia w Zagrzebiu doszło wówczas do starcia pomiędzy zdemobilizowanymi i przeważnie nieuzbrojonymi żołnierzami dwóch miejscowych pułków armii austro-węgierskiej a projugosłowiańskimi marynarzami oraz członkami Sokoła. Kilkanaście grudniowych ofiar śmiertelnych po stronie żołnierzy, wznoszących hasła patriotyczne i rewolucyjne, stało się męczennikami za niepodległość kraju, czczonymi przez tych wszystkich, dla których Jugosławia nie była spełnieniem wolnościowych aspiracji. Podobnie jak kilka miesięcy później w Czechach, mówiło się o nich po prostu „ofiary grudniowe" 48 . Do konfrontacji z policją w kolejne rocznice 5 grudnia dochodziło najczęściej na cmentarzach.

Przegląd kontrrocznic upamiętniających niepodległość niespełnioną (jak w Galicji Wschodniej) albo ofiary poległe w walce o prawo do samostanowienia (jak w Czechosłowacji i Jugosławii) czy też symbolizujących dążenie do demokratyzacji i decentralizacji kraju, w którym z każdym rokiem ubywało wolności (jak w Rumunii), wypada zakończyć na szczególnym sposobie celebry narodowego nieszczęścia. W okresie międzywojennym 4 czerwca każdego roku o 4:32 dzwony wszystkich węgierskich kościołów biły dla upamiętnienia największej katastrofy w dziejach państwa - traktatu w Trianon, odbierającego Węgrom większość terytorium wraz z większością ludności ${ }^{49}$. Według tego samego wzoru upamiętniano

${ }^{46}$ P.M. Majewski, „Niemcy sudeccy” 1848-1948. Historia pewnego nacjonalizmu, Warszawa 2007, s. 175-176.

${ }^{47}$ K. Wessely, Theater und Gedächtnis. Der 4. März und T.G. Masaryk als Gedächtnisorte?, w: Aufbruch und Krise. Das östliche Europa und die Deutschen nach dem Ersten Weltkrieg, red. B. Störtköhl, J. Stüben, T. Weger, München 2010, s. 191-192.

${ }^{48}$ J.P. Newman, Yugoslavia in the Shadow of War. Veterans and the Limits of State Building, 1903-1945, Cambridge 2015, s. 131-133.

49 Zob. A. Kovács-Bertrand, Der ungarische Revisionismus nach dem Ersten Weltkrieg. Der publizistische Kampf gegen den Friedensvertrag von Trianon (1918-1931), München 1997; M. Zeidler, Ideas on Territorial Revision in Hungary, 1920-1945, tłum. T.J. DeKornfeld, H.D. DeKornfeld, Wayne (NY) 2007. 
na Litwie „bunt” gen. Żeligowskiego i utratę Wilna. 9 października, w dzień żałoby narodowej, zamykano sklepy, a komunikacja publiczna nie kursowała ${ }^{50}$. Przywódcy wygłaszali mowy pełne goryczy i chęci rewanżu: „Brak Wilna czuje się aż do trzewi w naszych miastach i wsiach. Młodzi czy starzy, wszyscy mają w sercu obraz Litwy ze stolicą Gedymina i nikt nigdy nie będzie w stanie wymazać tego obrazu. [...] Czyż moglibyśmy kiedykolwiek zapomnieć i zamilknąć o Wilnie? Czyż moglibyśmy kiedykolwiek zapomnieć o przysiędze, złożonej wobec ojczyzny przez naszych ochotników wiosną 1919 r.? Nie moglibyśmy i nie mamy prawa zapomnieć. Ta przysięga nas wiąże. Nasi dawni wodzowie są w Wilnie pogrzebani, tam też leżą ci, którym zawdzięczamy narodowe odrodzenie"51.

Jeszcze jedną, ostatnią już alternatywą dla narodowych świąt wypełniających oficjalne i nieoficjalne kalendarze państw Europy Środkowo-Wschodniej była ... cisza. Wszędzie obok „panujących” większości żyły liczne mniejszości, a także indywidualiści, którzy nie mieli ochoty włączać się do świętującego tłumu. Bojkot oficjalnych obchodów to jakby druga strona rytuałów, znacznie rzadziej opisywana w prasie. Łatwiej trafić na jej ślady w policyjnych raportach, donoszących o pustkach na obchodach i sklepach otwartych pomimo święta państwowego. W regionach, w których mniejszość narodowa stanowiła przytłaczającą większość, państwo raczej nie podejmowało ryzyka konfrontacji z uczestnikami takiego bojkotu. Dlatego np. na zamieszkanym przez ludność węgierską południu Słowacji obchody 28 października pozostawały w okresie międzywojennym zupełną fikcją. Podróżny, który nie miałby świadomości, że odwiedzane państwo obchodzi właśnie swoje najważniejsze święto, nie wpadłby na to, chyba że życie zmusiłoby go do odwiedzin w lokalnym urzędzie. Nawet na terenach najostrzejszych konfliktów etnicznych godziny zamknięcia instytucji państwowych pozostawały i pozostają świętością dla wszystkich...

\section{Statuomachia}

XIX w. był stuleciem pomników. Stawiali je monarchowie i demokratyczne rządy, samorządy miejskie i stowarzyszenia ${ }^{52}$. Europa Środkowo-Wschodnia nie była co prawda regionem najciężej dotkniętym ową statuomanią, ale i jej to zjawisko nie ominęło. $\mathrm{W}$ regionie pełnym przebudzonych narodów, rządzonych najczęściej przez tradycyjne imperia z bożej łaski albo przez obce etnicznie państwo

${ }^{50}$ V. Davoliūte, The Making and Breaking of Soviet Lithuania. Memory and Modernity in the Wake of War, London-New York 2013, s. 29.

51 Typowe przemówienie premiera Smetony z lat 20; cyt. za: tamże, s. 27-28.

52 Zob. C. Tacke, Denkmal im sozialen Raum. Nationale Symbole in Deutschland und Frankreich im 19. Jahrhundert, Göttingen 1995; R. Koshar, From Monuments to Traces. Artifacts of German Memory, 1870-1990, Berkeley 2000. 
narodowe, monument już przed $1918 \mathrm{r}$. bywał sposobem na dobitne pokazanie, kto tu rządzi. Taki charakter miały rosyjskie pomniki w Królestwie, w szczególności ten poświęcony lojalistycznym generałom zabitym przez powstańców w noc listopadową. Podobnie inny warszawski pomnik Paskiewicza albo niemieckie monumenty w Poznaniu ${ }^{53}$. Najczęściej rolę takich znaków władzy i posiadania odgrywały pomniki głów panujących, takie jak potężny monument Marii Teresy w Wiedniu z końca lat 80. XIX w. czy też wyrażający wdzięczność Bułgarów dla Rosji pomnik Cara Oswobodziciela przed budynkiem parlamentu w Sofii z pierwszych lat następnego stulecia. Na cokoły wspięli się niektórzy wodzowie, zasłużeni w służbie monarchii, jak feldmarszałek Karol Schwarzenberg w Wiedniu albo feldmarszałek Joseph Radetzky (albo Josef Radecký) na Malostranském náměstí w Pradze, niesiony przez przedstawicieli różnych klas społecznych.

Przed 1914 r. konkurencja pomników narodowych dopiero zaczynała podkopywać symboliczną dominację monarchii. Czasami taki charakter przybierały upamiętnienia niemieckich walk $\mathrm{z}$ napoleońską Francją, będące jednocześnie emanacją woli panującego (w 1813 r. Fryderyk Wilhelm III zalecił poddanym stawianie pomników bohaterom; $\mathrm{z}$ tego czasu pochodzą także pierwsze tablice umieszczone w kościołach i informujące o parafianach poległych „za króla i ojczyznę") $)^{54}$. Wojny drugiej połowy wieku znacznie powiększyły liczbę pomników i tablic pamiątkowych, których bohaterowie zasłużyli się nie tyle dla monarchy, ile dla kraju i narodu. Świadectwem tej zmiany są upamiętnienia wojny francusko-pruskiej. Podobny charakter miał belgradzki monument walk o niepodległość i zjednoczenie, przedstawiający żołnierzy w bohaterskich pozach i wdzięcznych cywilów, ustawiony na wzgórzu Kalemegdan. Kiedy w 1915 r. miasto zajęły wojska austro-węgierskie, był jeszcze nieukończony. Znacznie bardziej ambitną narodową politykę historyczną prowadziły Węgry. W ostatnich latach XIX w. szerokim echem odbił się projekt milenijny obejmujący całą serię pomników upamiętniających tysiąclecie „zajęcia ojczyzny” (węg. honfoglalás), czyli przybycia Madziarów na Nizinę Węgierską pod koniec IX w. Pomniki milenijne miały być wyrazem siły, jaką emanowało węgierskie państwo, reprezentować „doktrynę państwową" zarówno wobec zagranicy, jak i własnych obywateli. Tylko dwa z siedmiu znalazły się na terenach etnicznie madziarskich. Dwa kolejne stanęły na terytorium dzisiejszej Słowacji, na wzgórzu Devín (węg. Dévény, niem. Theben) pod Bratysławą (wówczas Pozsony), obok ruin wielkomorawskiego zamku, oraz w Nitrze, mieście zdominowanym przez instytucje Kościoła katolickiego. Bliźniaczy do devínskiego pomnik, przedstawiający czuwającego wojownika $\mathrm{z}$ opuszczonym mieczem $\mathrm{w}$ dłoni, umieszczono na wzgórzu ponad Braszowem

${ }^{53}$ J. Tazbir, Warszawskie pomniki narodowej chwały $i$ - hańby, w: Warszawa. O czym mówiq pomniki i kamienie, red. K. Mórawski, A. Stawarz, Warszawa 2000, s. 13-28.

${ }^{54}$ V. Kessler, Druhý život válečných pomníků, Praha 2017, s. 45. 
(węg. Brassó, rum. Braşov, niem. Kronstadt), miastem zamieszkanym wówczas głównie przez Sasów siedmiogrodzkich i Rumunów. Jeszcze mniej Madziarów dałoby się odnaleźć w Mukaczewie (wówczas Munkács), zdominowanym przez ludność rusnacką i ortodoksyjnych Żydów, konsekwentnie ignorujących jakiekolwiek władze świeckie. Ostatnia pamiątka milenijna stała się jedną z atrakcji turystycznych Zemunia (niem. Semlin, węg. Zimony, obecnie dzielnica Belgradu, wówczas na terenie autonomicznej Chorwacji).

$\mathrm{W}$ wielu miejscach madziarskie monumenty dały lokalnym społecznościom impuls do stawiania własnych, często o polemicznej wymowie ideowej. Niemieccy mieszczanie Pressburga skontrowali devínskiego wojownika pomnikiem ku czci cesarzowej Marii Teresy. Ich rodacy z Braszowa zareagowali na taką samą prowokację, odsłaniając figurę nowożytnego reformatora religijnego, Johannesa Honterusa. Zdarzały się także bardziej spektakularne reakcje. W 1903 r. rumuńscy sprawcy wysadzili w powietrze pomnik w Braszowie. Figurę trzeba było odbudowywać, chociaż i tak długie trwanie nie było jej pisane ${ }^{55}$.

Stulecie statuomanii skończyło się w Europie Środkowo-Wschodniej falą obrazoburstwa. Zaczęło się jeszcze w czasie wojny od usuwania carskich pomników na terenach okupacji niemieckiej i austro-węgierskiej. Niektóre zdemontowali sami Rosjanie w trakcie odwrotu. W Wilnie ten los spotkał monumenty Katarzyny Wielkiej, Murawjowa i Puszkina. Serbski pomnik na Kalemegdan został zniszczony mniej więcej w tym samym czasie przez Austriaków. Po abdykacji Mikołaja II destrukcja nabrała tempa. Warszawskie rosyjskie pomniki zakończyły żywot na ogół w 1917 r., przy czym na jaw wyszło, że orły i lwy z pomnika Paskiewicza nie zostały wykonane z brązu, lecz ze spatynowanej blachy. Puste w środku i zaskakująco lekkie opuściły przestrzeń publiczną tak samo szybko jak kilkanaście miesięcy wcześniej ewakuujący się w pośpiechu Rosjanie ${ }^{56}$. W 1918 r. reszta rosyjskich pomników podzieliła los licznych cerkwi, demontowanych, wysadzanych w powietrze bądź przerabianych na budynki użyteczności publicznej. Nie lepiej powodziło się węgierskim statuom milenijnym. Rumuńska okupacja Siedmiogrodu w 1916 r. trwała co prawda krótko, czasu wystarczyło jednak na wysadzenie w powietrze ledwo co wracającego do siebie po zamachu madziarskiego woja. Kolejne figury padały bezpośrednio po I wojnie światowej, kiedy nowi właściciele bezpardonowo usuwali ślady węgierskich rządów. Jedynym położonym poza granicami potrianońskich Węgier zachowanym pomnikiem milenijnym jest wieża w Zemuniu. Stoi do dziś, będąc jedną z najbardziej charakterystycznych budowli Belgradu.

Burzenie starych pomników miało w Europie Środkowo-Wschodniej przynajmniej trzy fazy. Pierwszy krok polegał na usunięciu śladów obcego panowania.

55 B. Varga, The Monumental Nation. Magyar Nationalism and Symbolic Politics in fin-de-siècle Hungary, New York-Oxford 2016.

${ }^{56}$ J. Tazbir, dz. cyt., s. 16. 
Dzieło destrukcji rozpoczęło się niemalże dokładnie w chwili, gdy wybuchła niepodległość, a nawet, jak pokazują powyższe przykłady z Wilna i Siedmiogrodu - wcześniej. W Pradze niecały tydzień po ogłoszeniu Republiki tłum robotników z pomocą strażaków zniszczył kolumnę maryjną na Rynku Staromiejskim. Ten akt dał impuls do podobnych działań na prowincji. Ofiarą padły figury maryjne i rzeźby św. Jana Nepomucena, utożsamianego $\mathrm{z}$ kontrreformacją, a więc $\mathrm{z}$ obalonymi Habsburgami. Jeździecki pomnik cesarza Franciszka I został zrzucony z cokołu za stryczek uwiązany u szyi. Figura Radetzky’ego po drugiej stronie Wełtawy miała mniej spektakularny koniec. Zdemontowano ją po kryjomu, przykrywszy uprzednio płachtą. Atmosfera w większości przypadków była bardzo burzliwa, a uczestnicy kierowali się tyleż nacjonalizmem, co „nienawiścią klasową”. Akcja niszczenia kolumny maryjnej jest tego dobrym przykładem. Jej prowodyrami byli komuniści i anarchiści, śpiewano podczas niej rewolucyjne pieśni, a nad rynkiem powiewał czerwony sztandar ${ }^{57}$. To, co w Pradze było tajemnicą poliszynela, w Budapeszcie nie mogło pozostawiać żadnych wątpliwości. W chwili przejęcia władzy przez węgierskich komunistów w marcu 1919 r. monumentalne założenie pomnikowe na placu Bohaterów nie było jeszcze ukończone. Rewolucjoniści natychmiast obalili i zniszczyli pięć stojących już figur przedstawiających władców habsburskich, realizując postanowienie Komitetu Ludowego nakazującego „całkowite usunięcie albo przeniesienie wszystkich pomników, które urągają świadomości proletariatu bądź dobremu smakowi, przede wszystkim zupełnie bezwartościowe z punktu widzenia sztuki królewskie figury Habsburgów" ${ }^{58}$. Na pierwszy ogień poszedł przedostatni cesarz i król, Franciszek Józef I. W ramach przygotowań do obchodów 1 Maja w 1919 r., jedynych w krótkiej historii Węgierskiej Republiki Rad, kolumnę $\mathrm{z}$ archaniołem Gabrielem stojąca $\mathrm{w}$ centrum całego założenia pokryto czerwonym materiałem. W kilku miejscach miasta ustawiono tymczasowo figury robotników, Marksa, Engelsa, Liebknechta oraz zmarłego kilka miesięcy wcześniej Erwina Szabó, wybitnego teoretyka anarchosyndykalizmu i tłumacza Manifestu komunistycznego. Stojące jeszcze spiżowe wspomnienia minionej władzy przesłonięto, podobnie jak archanioła. Oprócz czerwonego pokrowca pomnik honweda na placu Dísz otrzymał ponadto inskrypcje „Czerwony żołnierz walczy nie przeciw swoim proletariackim braciom, lecz przeciw międzynarodowemu kapitałowi" 59 .

Kiedy opadł kurz rewolucyjnej i chaotycznej pierwszej fazy, rozpoczęła się druga. Jej motywem przewodnim było rozczarowanie z powodu niewystarczającej konsekwencji i radykalizmu zmian, nadrobienie tego, czego z różnych powodów nie udało się zniszczyć od razu. Kolejna fala przyniosła skoordynowaną akcję rozbiórki cerkwi prawosławnych w dawnym Królestwie, $\mathrm{z}$ warszawskim soborem

57 Z. Hojda, J. Pokorný, Pomníky a zapomníky, Praha 1996, s. 29-30.

58 Cyt. za: Á. von Klimó, Nation, Konfession, Geschichte. Zur nationalen Geschichtskultur Ungarns im europäischen Kontext (1860-1948), München 2003, s. 207 (tłum. M. Górny).

59 Tamże, s. 208 (tłum. M. Górny). 
św. Aleksandra Newskiego na czele (usunięty w połowie lat 20.). W Czechosłowacji na początku lat 20. doszło do kilku łudząco podobnych sekwencji wydarzeń, za każdym razem kończących się usunięciem z przestrzeni publicznej pomników niedających się pogodzić z poczuciem estetyki i moralności republikanów świeżej daty. Ofiarą tych działań, często połączonych z protestami mniejszości niemieckiej, padły m.in. pomniki cesarza Józefa II. Ta fala porwała także bratysławski pomnik Marii Teresy, mimo że jego fundatorem nie było węgierskie państwo, tylko mieszkańcy miasta. Jesienią 1921 r., kiedy cesarz Karol podjął próbę powrotu na Węgry, a nad Europą Środkowo-Wschodnią na krótko zawisło widmo powrotu do niedawno zakończonej wojny, na ulicach Bratysławy doszło do antyhabsburskich demonstracji, w trakcie których cesarzową zrzucono z cokołu. Podobne „korekty” przetaczały się przez wszystkie kraje regionu, z czasem godząc nie tylko w pamięć dawnych państw, ale także w mniejszości narodowe. Taki sens miała decyzja łotewskiego rządu z 1929 r., aby wysadzić w powietrze monument poświęcony zwycięstwu niemieckich ochotników z bolszewikami w bitwie o Rygę dziesięć lat wcześniej ${ }^{60}$.

Trzecia faza także mogła wiązać się ze zniszczeniem, ale destrukcja nie była jej celem. Chodziło o zastąpienie obalonych pomników nowymi, wśród których nas interesować będą te symbolizujące niepodległość. Często erygowanie takich symboli zwycięstwa było bezpośrednią kontynuacją fazy obrazoburczej. Bratysławscy manifestanci z 1921 r. nie poprzestali na strąceniu cesarzowej. Żądali także zastąpienia jej słowackim bohaterem z czasu wojny i ikoną niepodległości, Milanem Rastislavem Štefánikiem. Władze przychyliły się do tych postulatów i w 1927 r. rozpisano konkurs, w którym zwycięzcą został czeski rzeźbiarz Bohumil Kafka. Jego projekt składał się z dwóch elementów: postaci Štefánika w stroju lotnika stojącej na pylonie z godłem państwa. U stóp bohatera czuwać miał lew. I to właśnie zwierzę, symbol Królestwa Czeskiego, wzbudził wśród Słowaków kontrowersje na tyle silne, że nie zdążono już ukończyć prac przed upadkiem Czechosłowacji ${ }^{61}$.

Štefánik wcale nie był pomnikowym rekordzistą wśród pierwszoplanowych aktorów wydarzen 1918 r. Pod tym względem prym wiedli przywódcy młodych państw. Piłsudski i Masaryk stopniowo stawali się obiektami kultu, których figury szanujące się, większe (a czasami także mniejsze) miasto po prostu powinno posiadać. W wersji mieszanej, dynastyczno-narodowej, silną konkurencję dla Piłsudskiego i Masaryka stanowił król Aleksandar I Karadziordziewić, w kraju stopniowo powiększający pomnikową przewagę nad swoim ojcem, Piotrem I. Dziesiąta rocznica niepodległości w Polsce, Czechosłowacji i Jugosławii oznaczała

60 G. Swain, Politicising Commemoration in Twentieth-century Latvia, w: Aftermath. Legacies and Memories of War in Europe, 1918-1945-1989, red. N. Martin, T. Haughton, P. Purseigle, Farnham 2014 , s. 46.

${ }^{61}$ Z. Hojda, J. Pokorný, dz. cyt., s. 176-181. 
wzmożoną działalność budowlaną. Figury „ojców niepodległości” lub chociaż tablice im poświęcone dotarły nawet do małych miasteczek ${ }^{62}$. Wszyscy trzej mężowie stanu odeszli z tego świata w latach 30. Pierwszy - najmłodszy, Aleksandar, zastrzelony przez chorwackich zamachowców w czasie międzypaństwowej wizyty w Marsylii w 1934 r., Piłsudski i Masaryk z przyczyn naturalnych w 1935 i 1937 r. (przy czym prezydent Czechosłowacji złożył urząd już w 1935 r.). Ten czasowy zbieg okoliczności sprawił, że w Polsce, Czechosłowacji i Jugosławii nowa fala upamiętnień przywódców nadeszła dokładnie w tym samym czasie i trwała aż do wybuchu II wojny światowej. W miarę zbliżania się kataklizmu pomniki i sentencje na nich umieszczane nabierały charakteru trochę magicznego, a trochę rozpaczliwego. O Aleksandarze wieść gminna niosła, że jego ostatnie słowa brzmiały „Čuvajte mi Jugoslaviju” (ochrońcie moją Jugosławię) i to właśnie zdanie umieszczano na pomnikach króla pod koniec lat 30 .

\section{Groby i mauzolea}

Niemała część nowych pomników odnosiła się wprost do zbrojnej walki o niepodległość kraju. Zgodnie z tradycją czasem przedstawiały żołnierzy, znacznie częściej przyjmując postać symboliczną: kamieni, obelisków, krzyży. Nieprzypadkowo budziły skojarzenia $\mathrm{z}$ nagrobkami, taki właśnie był bowiem ich rodowód.

Jeszcze przed jesienią 1918 r. prawdziwym sepulkralnym imperium okazały się Austro-Węgry. Nie tylko dlatego, że na ich obszarze, przede wszystkim w Galicji i na terenie dzisiejszej Słowenii, toczyły się wyjątkowo krwawe walki. Także dlatego, że do sprawy ekshumacji i pochówków żołnierskich podeszły z wyjątkową powagą. Już jesienią 1914 r. zaczęto pracę nad porządkowaniem pobojowisk, a kilka miesięcy później rozpoczęto zorganizowane pochówki połączone z ekshumacjami z mogił polowych ${ }^{63}$. Skala tych działań była imponująca. W czasie wojny trzy Oddziały Grobów Wojennych w Krakowie i Inspekcje Grobów Wojennych w Przemyślu i Lwowie wybudowały ponad pół tysiąca stałych cmentarzy i prawie trzy razy więcej tymczasowych ${ }^{64}$. Od 1916 r. współpracował z nimi nowy oddział dla terenów okupowanych w Królestwie. W przypadku stałych nekropolii wojennych nie chodziło ani o powtarzalne projekty, ani też o równe rzędy jednakowych krzyży typowe dla frontu zachodniego. Miejsca ostatniego spoczynku austro-węgierskich żołnierzy (oraz ich rosyjskich przeciwników, bo

62 J. Szczepański, Organizacje kombatanckie i paramilitarne na Mazowszu Pótnocnym w okresie międzywojennym, „Zeszyty Naukowe Ostrołęckiego Towarzystwa Naukowego” 23, 2009, s. 35.

${ }^{63}$ M. Łopata, Groby żydowskich żotnierzy Wielkiej Wojny w Galicji, w: Znaki pamięci. Materialy z konferencji naukowej, Gorlice, 27.10.2007 r., red. M. Dziedziak, Gorlice 2008, s. 5-26.

${ }^{64}$ B.K. Nykiel, Vom Vergessen zu einer neuen kollektiven Erinnerung. Gegenwart und Vergangenheit westgalizischer Soldatenfriedhöfe, w: Schlachtfeld Galizien, red. C. Reichl-Ham, I. Nöbauer, W. Fröhlich, Wien 2016, s. 216 (tam literatura przedmiotu). 
galicyjskie cmentarze są międzynarodowe) to przemyślane kompozycje najlepszych architektów (w tym dwóch współtwórców „stylów narodowych”: Dušana Jurkoviča i Jana Szczepkowskiego), łączące różne materiały, style i zawsze starannie dopasowane do otaczającego krajobrazu. Przy ich budowie pracowały tysiące ludzi, najczęściej rosyjskich i włoskich jeńców wojennych, których praca miała służyć przyszłej chwale monarchii, ponieważ galicyjskie cmentarze były właśnie inwestycją w przyszłość. „Z opisów wynika - pisze Kamil Ruszała - że $\mathrm{w}$ projektach tak dobierano element zieleni, by wpisywała się ona w przestrzeń cmentarza także po wielu latach, gdy posadzone rośliny osiągną już pełne rozmiary. Podobnie pod względem infrastrukturalnym obiekty tworzono w sposób przystępny dla przyszłych pielgrzymów, chcących odwiedzić grób członka swojej rodziny. Postawiono kamienne drogowskazy (nierzadko także miały one bardziej rozwinięte formy kapliczek-drogowskazów), zbudowano drogi, mostki, a nawet ławki, utrzymane w stylu architektonicznym całego cmentarza"65.

Upadek monarchii habsburskiej nie od razu zakończył działalność austro-węgierskich architektów. Jak zauważa Mirosław Łopata, niektóre tabliczki imienne na galicyjskich cmentarzach podają stopnie wojskowe w języku polskim. Świadczy to jednoznacznie o kontynuacji prac po listopadzie 1918 r., ponieważ przedtem stosowano w tym celu wyłącznie język niemiecki bądź węgierski ${ }^{66}$. Rozkład wielkiego dzieła zaczął się jeszcze zanim dobiegło ono końca. Zima z 1918/1919 r. była surowa w całej Europie Środkowo-Wschodniej i drewniane krzyże na niestrzeżonych cmentarzach okazały się wyjątkowo podatne na kradzież. Potem zaczęły znikać także elementy metalowe. Policja natrafiała niekiedy na całe składy złomu kradzionego z cmentarzy. Okoliczni chłopi potrafili wykorzystać wszystko, włącznie $\mathrm{z}$ cmentarnymi murkami ${ }^{67}$. Wkrótce destrukcja zyskała paradoksalne usprawiedliwienie w postaci fali krytyki wobec austro-węgierskiej architektury galicyjskich nekropolii, wyrażającej jakoby obcy narodowi polskiemu gust artystyczny ${ }^{68}$. Nowe cmentarze bojowników o niepodległość miały reprezentować inną estetykę.

Problem utrzymania galicyjskich (a także słoweńskich, królewiackich, białoruskich, ukraińskich, litewskich i łotewskich) cmentarzy wojennych wynikał w znacznej mierze ze zmiany granic. Zmarli nie tylko spoczywali daleko od domu. Po 1918 r. znajdowali się w dodatku często w obcym kraju. Miejscowi rzadko poczuwali się do odpowiedzialności za to kłopotliwe dziedzictwo Wielkiej Wojny,

${ }^{65} \mathrm{~K}$. Ruszała, „Żołnierze cesarza odeszli na spoczynek”. Zachodniogalicyjskie cmentarze wojenne i pochówki Słoweńców z armii austro-węgierskiej, w: W Galicji i nad Socza. Polacy i Słoweńcy na frontach I wojny światowej, red. A. Cetnarowicz, D. Nećak, S. Pijaj, B. Todorović, Kraków 2016, s. 105-116, cyt. ze s. 109.

${ }^{66}$ M. Łopata, dz. cyt., s. 19.

67 J. Pałosz, The Military Cemetery as a Form of the Cult of the Fallen Soldier. The History of the Idea and its Destruction on the Example of Austro-Hungarian Cemeteries in "Russian Poland”, „Remembrance and Solidarity” 2, 2014, s. 299-325.

${ }^{68}$ B.K. Nykiel, dz. cyt., s. 220. 
a rodzinom nie było łatwo dbać o odległe groby. Dotyczyło to nie tylko cmentarzy wojskowych, ale także kwater żołnierskich na cmentarzach parafialnych. Już w pierwszych latach po wojnie polscy proboszczowie zaczęli likwidować kwatery żołnierzy rosyjskich, słusznie licząc na to, że nikt się już o nie nie upomni ${ }^{69}$. Kiedy już państwo brało sprawy we własne ręce, raczej nie uwzględniało stanowiska krewnych. Rządzone przez partię programowo utożsamiającą się z weteranami Włochy nie pytały nikogo o zdanie, rozpoczynając olbrzymią akcję ekshumacji $\mathrm{z}$ frontu nad Soczą na cmentarze w głębi kraju. Tereny najcięższych walk włącznie z Kobaridem (Caporetto) zostały oficjalne anektowane przez Rzym już w 1920 r., a po 1922 r. wybudowano tam kilka wielkich założeń cmentarnych, z najbardziej znanym carnarium na wzgórzu Gradič, otwartym uroczyście przez samego Duce we wrześniu $1938 \mathrm{r}^{70}$

Faszystowskie Włochy uprawiały $\mathrm{w}$ wielkim stylu politykę, która w gruncie rzeczy była bliska niemal wszystkim europejskim państwom narodowym. Tyle że w Europie Środkowo-Wschodniej pod ochroną państwa i energicznie działających organizacji społecznych znalazły się wyłącznie nekropolie bojowników formacji narodowych, a więc niewielkiej części milionów poległych. Działał tu ten sam mechanizm, który tak sprawnie rozdzielał żyjących weteranów na sieroty po „obcych” armiach i „niepodległościowców” ${ }^{1}$. Wyrazem pośmiertnej hierarchii stały się takie nekropolie jak Cmentarz Braci w Rydze (na którym aż do 1945 r. leżeli wyłącznie łotewscy bojownicy o niepodległość), Cmentarz Orląt Lwowskich czy całkiem liczne cmentarze i kwatery legionistów na nekropoliach „ogólnowojskowych". Ci ostatni niekiedy wyświadczali przysługę poległym kolegom $z$ innych armii, ratując przed likwidacją także ich groby znajdujące się na tych samych cmentarzach ${ }^{72}$.

Aż do wybuchu II wojny światowej podejmowano budowę kolejnych cmentarzy i mauzoleów, często na polach bitew odgrywających szczególną rolę w polityce historycznej państwa. Jedno z najbardziej imponujących założeń tego rodzaju mauzoleum żołnierzy rumuńskich poległych w bitwie pod Maraşești - udostępniono zwiedzającym w 1938 r. Kostiuchnówka, miejsce największej bitwy stoczonej przez Legiony Polskie w 1916 r., stała się w okresie międzywojennym skansenem pola bitewnego $^{73}$. Inny sposób upamiętnienia wybrano w Jastkowie, w pobliżu Lublina,

69 Tamże, s. 310.

70 K. Ruszała, „Requiem aeternam”. Groby Galicjan poległych w I wojnie światowej na terenie dzisiejszej Słowenii, w: W Galicji i nad Socza..., s. 97.

71 J. Eichenberg, Kämpfen für Frieden und Fürsorge. Polnische Veteranen des Ersten Weltkriegs und ihre internationalen Kontakte, 1918-1939, München 2011.

72 Cmentarze I wojny światowej, Cmentarz nr 171 - Łowczówek, http://www.cmentarze.gorlice.net.pl (4 VI 2018).

73 M. Górny, Dílna velké doby. Zrození nového člověka za první světové války, w: Svůdnost sociálního experimentu. Nový člověk 20. století, red. L. Fasora, J. Hanuš, D. Nečasová, Praha 2018, s. $161-174$. 
gdzie od 31 lipca do 3 sierpnia 1915 r. toczyły się walki pomiędzy oddziałami Legionów Polskich a wojskami rosyjskimi. W 1924 r., podczas zjazdu uczestników bitwy, postanowiono, że na piętnastą rocznicę walk na cmentarzu wzniesiony zostanie pomnik, a w sąsiedztwie powstanie szkoła powszechna. Przed rocznicą w 1930 r. rozdzielono poległych - szczątki żołnierzy austriackich i rosyjskich ekshumowano i przeniesiono na cmentarz wojenny w Garbowie, a z cmentarza w Niedrzwicy Kościelnej przeniesiono do Jastkowa zwłoki 8 spoczywających tam legionistów. Utworzony w ten sposób, już symbolicznie jednoznaczny, cmentarz żołnierzy Legionów Polskich uporządkowano, ogrodzono, ustawiono betonowe krzyże, wzniesiono pomnik oraz szkołę, które zaprojektował ceniony w Lublinie architekt, Bohdan Kelles-Krauze ${ }^{74}$. W następnych latach w Jastkowie co roku organizowano obchody upamiętniające bitwę z 1915 r., w których brali udział kombatanci, dawni legioniści, przedstawiciele władz wojewódzkich i lokalnych, członkowie organizacji i stowarzyszeń społecznych, młodzież i nauczyciele ${ }^{75}$. W Zborowie, miejscu najważniejszej bitwy legionów czechosłowackich, Republika Czechosłowacka ufundowała pomnik poległym. Odbywały się tam uroczystości rocznicowe, w których obok żołnierzy czechosłowackich uczestniczyli polscy gospodarze. Wspólnie defilowano, organizowano pokazy lotnictwa, a w 1927 r., w dziesiątą rocznicę bitwy, odbył się wieloetapowy maraton na trasie Zborów - Praga ${ }^{76}$.

Cmentarze wojenne stanowily jeden z elementów polityki historycznej państwa. Kryły w sobie jednak także ten sam potencjał konfliktu co rocznice niepodległości. Do spięć dochodziło zwykle w okolicach Zaduszek, kiedy pozapaństwowe (a czasami antypaństwowe) rytuały manifestowały się zarówno na terenie cmentarzy, jak i w innych miejscach upamiętniających poległych. W Austrii w tym dniu odbywały się przy cmentarzach antywojenne demonstracje socjaldemokratów ${ }^{77}$. W międzywojennej Jugosławii sceną najbardziej poruszających wydarzeń stał się cmentarz Mirogoj w Zagrzebiu. 1 listopada Chorwacka Partia Prawa, kontestująca zjednoczenie narodów Jugosławii, organizowała tu co roku manifestacje ku pamięci żołnierzy poległych w walce o chorwacką suwerenność. Upamiętniali habsburskich wojskowych narodowości chorwackiej, a także ofiary zajść w Zagrzebiu z 5 grudnia 1919 r., o których już wspominaliśmy. W 1932 r. na cmentarzu Mirogoj odsłonięto symboliczny grób tych ostatnich, będący widocznym znakiem sprzeciwu wobec polityki historycznej państwa. Na Wszystkich Świętych kwiaty składano także na grobach ważniejszych wojskowych, np. gen. Antuna Lipošciaka, niegdyś austro-węgierskiego gubernatora wojskowego w Lublinie.

74 P. Prezydent Rzplitej gościem Ziemi lubelskiej, „Ilustrowany Kurier Codzienny” 5 VI 1931, s. 10.

${ }^{75}$ L. Zugaj, Dzieje Jastkowa i okolic. Od zarania do 1939 roku, Lublin 2010, s. 51-56.

${ }^{76}$ M. Górny, dz. cyt., s. 170-173.

77 C. Edgecombe, M. Healy, Competing Interpretations of Sacrifice in the Postwar Austrian Republic, w: Sacrifice and Rebirth..., s. 22. 
W 1924 r. cmentarz Mirogoj na krótko zmienił się z areny politycznej walki w pole bitwy. Na terenie nekropolii policja starła się z chorwackimi komunistami, którzy zebrali się, by uczcić pamięć Aliji Alijagicia, towarzysza powieszonego za (udany) zamach na ministra spraw wewnętrznych. Jego grób zyskał policyjną obstawę, starającą się nie dopuścić towarzyszy zabitego, co skończyło się bijatyką pomiędzy nagrobkami. Aby zapobiec powtórce, władze ekshumowały Bośniaka na cmentarz w jego rodzinnej wsi ${ }^{78}$. Areną podobnych wydarzeń były w okresie międzywojennym cmentarze we Lwowie. Na Zielone Świątki 1930 r. panichidy odbyły się tu na cmentarzach Janowickim i Łyczakowskim, a w uroczystościach na mogiłach Ukraińskich Strzelców Siczowych wzięło udział kilka tysięcy osób. Polscy tajniacy zwrócili uwagę szczególnie na wieńce z drutu kolczastego, składane na grobach bojowników o ukraińską niepodległość ${ }^{79}$.

Groby ukraińskie w II Rzeczypospolitej, chorwackie i słoweńskie w Jugosławii czy węgierskie w Czechosłowacji należały do tej samej kategorii „kontrpamięci”, alternatywnej wobec państwowego kultu bojowników o niepodległość nie dlatego, że przedmiot pamięci (czyli polegli) należeli do armii upadłych imperiów, lecz dlatego, że walczyli o niepodległość innego narodu. Związane z nimi rytuały i symbole nie różniły się zbytnio od tych oficjalnych i państwowych. Jedne i drugie operowały metaforą bohaterskiej śmierci, dającej żyjącym prawo do posiadania terytorium, o które i za które walczyli polegli. Narody panujące miały w tym współzawodnictwie dużo lepszą pozycję, dysponowały bowiem finansowymi i symbolicznymi zasobami państwa, chociaż oczywiście w odpowiednich okolicznościach role mogły się odwrócić. Wyrazem tej dominacji stała się centralizacja pamięci walk o niepodległość. Jej najbardziej widoczną fizyczną formą były groby nieznanego żołnierza.

\section{Groby nieznanego żołnierza}

Idea i sposób wykonania były importem z Francji i Wielkiej Brytanii, choć i w tym aspekcie polityki pamięci pomiędzy poszczególnymi państwami Europy Środkowo-Wschodniej szybko ujawniły się różnice. Najpierw okazało się, że zwycięzcy są dużo bardziej skorzy do naśladowania wzorów z Paryża i Westminsteru niż przegrani: Austria, Węgry i Bułgaria. Praski grób nieznanego żołnierza na Rynku Staromiejskim został zrealizowany w 1922 r., a zanim to nastąpiło zdążono już położyć kamień węgielny pod coś znacznie bardziej imponującego: górujące nad miastem świeckie sanktuarium czynu legionowego. Prace nad warszawskim Grobem Nieznanego Żołnierza zaczęto w 1923 r., w czasie gdy w Bukareszcie odsłaniano właśnie skromne założenie architektoniczne poświęcone rumuńskim bohaterom wojennym. Podobnie jak w Pradze, istniały już wtedy prowizoryczne

\footnotetext{
78 J.P. Newman, dz. cyt., s. 168-174.

79 G. Mazur, dz. cyt., s. 127.
} 
symboliczne groby. W Zaduszki 1920 r. premier Wincenty Witos i marszałek Sejmu Wojciech Trąmpczyński oddali hołd poległym przy sarkofagu ustawionym tymczasowo w al. 3 Maja. Kolejne upamiętnienie znalazło się w warszawskiej katedrze. Prace nad projektem centralnego miejsca pamięci szły tymczasem opornie i gdyby nie podarowany państwu piaskowiec, nadający się do obróbki, być może utknęłyby na dłużej. Tajemniczym ofiarodawcą okazało się Zjednoczenie Polskich Stowarzyszeń w Rzeczypospolitej, związana z endecją federacja organizacji społecznych, stawiająca sobie za cel dobro ojczyzny, pod którym to hasłem rozumiano zarówno poprawę jakości stanowionego prawa, budowę stadionu w Warszawie, jak i numerus clausus oraz bliżej niesprecyzowaną walkę z bolszewizmem ${ }^{80}$. Także inne wydarzenia związane $\mathrm{z}$ budową wskazywały na ingerencję kierownictwa endecji, starającego się w miarę możliwości postponować Piłsudskiego: nie zapraszać go na uroczystości, nie umieszczać na płytach pamiątkowych bitew, w których dowodził itd. Ostatecznie Grób odsłonięto 2 listopada 1925 r., a w ciągu kolejnej dekady utrwaliła się tradycja organizowania apeli poległych na Wszystkich Świętych i w Święto Niepodległości ${ }^{81}$.

Oprócz najbardziej znanego, warszawskiego Grobu Nieznanego Żołnierza w wyniku inicjatyw społecznych powstały pomniki w innych miastach. Pierwszy, zlokalizowany na placu przed katedrą w Łodzi, miał formę monumentalnej płyty nagrobnej z czarnego, polerowanego marmuru z napisem: „Nieznanemu Żołnierzowi miasto Łódź - rok 1925”. Zaprojektował ją Stanisław Kazimierz Ostrowski, pracujący w tym czasie także nad Grobem Nieznanego Żołnierza w Warszawie ${ }^{82}$. W Radomiu w nocy z 2 na 3 maja 1925 r. nieznany fundator powtórzył wariant wypróbowany w stolicy i zostawił przed wejściem do kościoła garnizonowego pokaźnych rozmiarów marmurową płytę z napisem „Nieznanemu Żołnierzowi Poległemu w Obronie Ojczyzny”. Władze miasta płytę wyeksponowały i odpowiednio zagospodarowały otoczenie pomnika. Podobna historia zdarzyła się w Krakowie, gdzie dyskusje dotyczące ufundowania pomnika rozpoczęły się jesienią 1924 r., a w nocy z soboty 13 na niedzielę 14 czerwca 1925 r. „zajechała przed Pomnik Grunwaldzki platforma, na której przywieziono wielką kamienną płytę i złożono ją na gazonie przed Pomnikiem Grunwaldzkim. Na płycie długości 2 metry a szerokości 1 metr, wyryty jest napis treści następującej: NIEZNANEMU ŻOŁNIERZOWI POLSKIEMU POLEGŁEMU ZA OJCZYZNĘ 1914-1920"83.

W Krakowie przypuszczano, że zachowującym anonimowość fundatorem był Marian Dąbrowski, dziennikarz i największy potentat prasowy w Polsce

80 Zjednoczenie Polskich Stowarzyszeń w Rzeczypospolitej. Sprawozdanie z działalności jego od początku istnienia do roku 1924, Warszawa 1924, passim.

${ }^{81}$ J. Wysocki, Grób Nieznanego Żotnierza, w: Warszawa. O czym mówia..., s. 104-134.

${ }^{82}$ Ci, co przybywają odwiedzić polski Manchester, „Łódź w Ilustracji” 2, 1925, nr 12, s. 3.

83 Złożenie płyty pamiątkowej dla Nieznanego Żotnierza przed Pomnikiem Grunwaldzkim w Krakowie, „Ilustrowany Kurier Codzienny” 5 VI 1925, s. 10. 
międzywojennej, właściciel „Ilustrowanego Kuriera Codziennego”. Tego samego dnia, 14 czerwca 1925 r. na Cmentarzu Rakowickim w Krakowie odsłonięto uroczyście pomnik ułanów rokitniańskich - legionowych kawalerzystów oraz ich dowódcy, rtm. Zbigniewa Dunin-Wąsowicza, poległych w bitwie pod Rokitną 13 czerwca 1915 r., pochowanych na cmentarzu w Rarańczy, a w lutym 1923 r. przeniesionych do Krakowa ${ }^{84}$. W sierpniu 1925 r. w Lublinie na placu Litewskim odsłonięto Pomnik Nieznanego Żołnierza ufundowany przez Towarzystwo Gimnastyczne „Sokół”. W Bydgoszczy zaś wzniesienie polskiego pomnika poprzedził akt zburzenia w latach 1921-1922 obelisku z 1880 r. ku czci oficerów i żołnierzy poległych na wojnach prowadzonych w XIX w. przez Królestwo Prus. W mieście, w którym po przyłączeniu do Polski w 1920 r. mieszkało ponad 400 uczestników powstania wielkopolskiego (i z pewnością nie mniej weteranów armii pruskiej i niemieckiej), zrodziła się inicjatywa upamiętnienia poległych powstańców. Na bydgoskim Cmentarzu Nowofarnym istniał autentyczny grób niezidentyfikowanego żołnierza Armii Wielkopolskiej, ciężko rannego w czasie walk w czerwcu 1919 r., który zmarł, nie odzyskawszy przytomności, w pruskim szpitalu wojskowym. Szczątki poległego ekshumowano 7 sierpnia 1925 r., złożono do metalowej trumny, a następnego dnia rano ceremonię powtórnego pogrzebu rozpoczęło nabożeństwo w kaplicy cmentarnej. „Przeszło 100 Towarzystw i tysiące tłumu uczestniczyło w uroczystości, samych sztandarów Towarzystw Powstańców i Wojaków naliczono przeszło $50 " 85$. Przeszli ulicami miasta, przybranymi w barwy narodowe, w kondukcie żałobnym ${ }^{86}$.

Bydgoski Grób Nieznanego Powstańca Wielkopolskiego stał się ważnym centrum ceremonii upamiętniających wydarzenia $\mathrm{z}$ okresu Wielkiej Wojny i walk o odzyskanie niepodległości - obchodzono przy nim święta państwowe, rocznice powstania wielkopolskiego, święta pułków stacjonujących w garnizonie bydgoskim oraz uroczystości organizowane przez Związek Hallerczyków, którzy 8 października 1928 r. złożyli w grobie ziemię pobraną z grobów żołnierzy Armii Hallera w St. Hilaire we Francji ${ }^{87}$. Jednocześnie odgrywał rolę charakterystyczną dla upamiętnień na terenach mieszanych etnicznie: niedwuznacznie dawał do zrozumienia niemieckiej mniejszości narodowej, kto tu jest panem.

W czasie, gdy w Polsce problem upamiętnienia bohaterów walk o niepodległość był już rozwiązany, w Królestwie SHS zaczynała się dopiero dyskusja nad optymalnym umiejscowieniem jugosłowiańskiego Grobu Nieznanego Żołnierza.

${ }^{84}$ Pomnik bohaterów na cmentarzu rakowickim w Krakowie, „Ilustrowany Kurier Codzienny” 14 VI 1925, s. 1; Pomniki sławy. W dziesiąta rocznicę szarży rokitniańskiej, tamże, s. 2-3.

${ }^{85}$ Prezydent F.I.D.A.C.'u w Polsce, „Kurier Poznański” 11 VIII 1925, s. 3.

${ }^{86}$ Uroczystości ku czci „Nieznanego Żotnierza” w Bydgoszczy, „Polska Zbrojna” 5, 1925, nr 218, s. 1.

${ }^{87}$ Historia Pomnika Grób Nieznanego Powstańca Wielkopolskiego, TPPW 1918/1919 koło Bydgoszcz, http://tppw.wikidot.com/historia-pomnika (4 VI 2018). 
Na wzgórzu Avala nieopodal Belgradu znajdowała się tymczasowa konstrukcja, kurhan ze szczątkami młodego Serba ekshumowanego z jednego z pól bitewnych 1914 r. Początkowa propozycja, by przenieść go na wzgórze Kalemegdan w Belgradzie, z grubsza tam, gdzie stał zniszczony przez habsburskich okupantów pomnik zjednoczenia, została odrzucona na rzecz lokalizacji położonej dalej od miasta. Ostatecznie wybór padł na dotychczasowe miejsce spoczynku zwłok, wzgórze Avala, a sanktuarium zaprojektowane przez najwybitniejszego chorwackiego rzeźbiarza Ivana Meštrovicia zostało ukończone w 1934 r., krótko przed tragiczną śmiercią króla Aleksandara. Prochy Nieznanego Żołnierza przeniesiono z tymczasowego miejsca pochówku na Avalę w 1938 r.

W porównaniu z tymi wczesnymi adaptacjami idei grobu nieznanego żołnierza państwa, które przegrały wojnę, były opóźnione. Austriacki grób udostępniono publiczności w 1927 r., węgierski w 1928, a bułgarski w 1929 r. Nie była to jedyna różnica pomiędzy zwycięzcami i pokonanymi. Mimo politycznych konfliktów, Austriacy, Węgrzy i Bułgarzy nie mieli problemu typowego dla nowych państw Europy Środkowo-Wschodniej, czyli konieczności wyboru właściwych zwłok - nieznany żołnierz służył w mundurze regularnej armii. W Polsce, Czechosłowacji i Jugosławii była to kwestia istotna, wyraz polityki historycznej państwa. W polskim przypadku wybór (obrona Lwowa) można uznać za kompromis. Pobojowisko, z którego miano sprowadzić zwłoki, wybrano spośród kilkunastu miejsc walk stoczonych po 1918 r. Uniknięto tym samym niebezpieczeństwa, że grób stanie się sanktuarium jednej tylko grupy weteranów, np. legionistów. Uroczystego odsłonięcia dokonano również w „niepolityczne” Zaduszki. Inaczej stało się w Czechosłowacji, gdzie „nieznany” (a w rzeczywistości znany z imienia i nazwiska) poległy należał do czechosłowackich legionistów walczących w bitwie pod Zborowem, wziął więc udział w kluczowym epizodzie legionowej epopei. Podobnie jak w Polsce i Jugosławii, jego zwłoki transportowano pociągiem, a ich przybycie do kolejnych miast było okazją do patriotycznych uroczystości. Natomiast inaczej niż w Warszawie do ponownego pochówku w Grobie Nieznanego Żołnierza (w kaplicy staromiejskiego ratusza) doszło w dniu jak najbardziej politycznym, 1 lipca, w wigilię zborowskiej bitwy. Ten sam, czysto legionowy charakter miał Památník Osvobození na Žižkovie w Pradze, mauzoleum połączone z instytucją badawczą, kierowaną przez gen. Rudolfa Medka. Także tu nie ulegało wątpliwości, że uroczysty pochówek dotyczyć będzie wyłącznie weteranów czechosłowackich legionów, w przyszłości - jak chcieli legioniści i sam Medek - miało to być także miejsce ostatniego spoczynku Masaryka, który jednak miał inne plany. Grób Nieznanego Jugosłowiańskiego Żołnierza reprezentuje jeszcze inny wariant hierarchizacji pól bitewnych. Poległy był serbskim żołnierzem (nie zaś np. słoweńskim lub chorwackim ochotnikiem walczącym po stronie Serbii). Wieloetniczny charakter państwa uszanowano w inny, mniej dosłowny sposób. Architektem mauzoleum został Chorwat, a granit użyty do jego budowy 
pochodził z Bośni. Kariatydy wyrzeźbione przez Meštrovicia miały symbolizować „szczepy” Jugosławii ${ }^{88}$.

Symbolika, odwołująca się do najszlachetniejszych cech natury ludzkiej, była zresztą wspólna wszystkim grobom nieznanych żołnierzy. Importowana z Zachodu idea polegała wszak na tym, że Nieznany będzie reprezentować wszystkich. W poruszającym kazaniu, wygłoszonym $\mathrm{w}$ dniu powtórnego pochówku szczątków anonimowego obrońcy Lwowa, ks. prałat Antoni Szlagowski mówił: „Kto jesteś ty - nie wiem. Gdzie dom twój rodzinny - nie wiem, kto twoi rodzice - nie wiem i wiedzieć nie chcę i wiedzieć nie będę, aż do dnia sądnego. Wielkość twoja w tym, żeś nieznany. [...] Czymże i na Boga jesteś, szary żołnierzu, nieznany, bezimienny? Ty jesteś odwieczny geniusz bojowy Narodu, zowiesz się Męstwo. Ty jesteś niespożyta, niezmożona moc ideałów narodowych, zowiesz się Poświęcenie. Ty jesteś wszechzwycięska niepodległość ducha narodowego, zowiesz się Wolność!"89.

Problem, nie tylko zresztą polski, polegał na tym, czyja to była wolność.

\section{Podsumowanie}

Niepodległość albo zjednoczenie oraz upamiętnienie bohaterów walki o te najwyższe z punktu widzenia państwa - wartości stanowiły fundament polityki historycznej w międzywojennej Europie Środkowo-Wschodniej. Zarazem polityka ta, wyrażana wyborem symbolicznych dat świątecznych czy też budową (albo usuwaniem) pomników, podporządkowywała sobie przestrzeń publiczną, tworząc nowe znaki, które wywoływały emocje, czasami skrajne ${ }^{90}$. Konflikt, w najlepszym razie werbalny, niekiedy zbrojny, towarzyszył temu procesowi od samego początku. Symbole, do których odwoływała się władza, były jedynie jedną $\mathrm{z}$ wielu możliwości. Pozostałe, reprezentowane przez mniejszości etniczne, opozycję polityczną (włącznie z partiami komunistycznymi, o których strategii wobec symboliki niepodległości w niniejszym tekście nie pisaliśmy) i grupy interesu, pozostawały w okresie międzywojennym potencjalną alternatywą dla tych oficjalnych, gotowe do ich zastąpienia przy pierwszej nadarzającej się okazji. Stanowiły estetyczny naddatek politycznych programów, scenariusze do wykorzystania w przypadku, gdy dotychczas rządzący staną się uciskaną mniejszością, a ci dotąd marginalizowani otrzymają przynajmniej jakąś namiastkę własnej niepodległości.

88 A. Ignjatović, From Constructed Memory to Imagined National Tradition. The Tomb of the Unknown Yugoslav Soldier (1934-38), „Slavonic and East European Review” 88, 2010, nr 4, s. 624-651.

${ }^{89}$ J. Wysocki, dz. cyt., s. 115-116.

90 P. Steinbach, Pamięć - upamiętnianie - polityka historyczna, w: Polsko-niemieckie miejsca pamięci, t. 4: Refleksje metodologiczne, red. R. Traba, H.H. Hahn, współpr. M. Górny, K. Kończal, Warszawa 2013, s. 282. 


\section{Bibliografia}

Akt 5 listopada i jego konsekwencje dla Polski i Europy, red. J. Kłaczkow, K. Kania, Z. Girzyński, Toruń 2016

L. Antonowicz, Narodziny Drugiej Rzeczypospolitej ze stanowiska prawa międzynarodowego, „Przegląd Sejmowy" 1998, nr 5(28), s. 17-22

P. Barišić, Gedenktage in Kroatien als Medium der Geschichtserzählung, w: Der Kampf um Gedächtnis. Öffentliche Gedenktage in Mitteleuropa, red. E. Brix, H. Steckl, Wien 1997, s. 337-354

M. Bobrzyński, Wskrzeszenie państwa polskiego. Szkic historyczny, t. 1, Kraków 1920

C. Brzoza, A.L. Sowa, Historia Polski 1918-1945, Kraków 2006

V. Davoliūte, The Making and Breaking of Soviet Lithuania. Memory and Modernity in the Wake of War, London-New York 2013

R. Dmowski, Pisma, t. 5: Polityka polska i odbudowanie państwa, cz. 1: Przed wojna; Wojna r. 1917, Częstochowa 1937

R. Dmowski, Pisma, t. 6: Polityka polska i odbudowanie państwa, cz. 2: Wojna od r. 1917; Pokój, Częstochowa 1937

J. Eichenberg, Kämpfen für Frieden und Fürsorge. Polnische Veteranen des Ersten Weltkriegs und ihre internationalen Kontakte, 1918-1939, München 2011

Z. Gnat-Wieteska, Akt 5 listopada, jego postanowienia i znaczenie, „Niepodległość i Pamięć” 23, 2016, nr 2(54), s. 13-22

M. Górny, Dílna velké doby. Zrození nového člověka za první světové války, w: Svůdnost sociálního experimentu. Nový člověk 20. století, red. L. Fasora, J. Hanuš, D. Nečasová, Praha 2018, s. 161-174

Z. Hojda, J. Pokorný, Pomníky a zapomníky, Praha 1996

A. Ignjatović, From Constructed Memory to Imagined National Tradition. The Tomb of the Unknown Yugoslav Soldier (1934-38), „Slavonic and East European Review” 88, 2010, nr 4, s. 624-651

V. Kessler, Druhý żivot válečných pomníkư, Praha 2017

Á. von Klimó, Nation, Konfession, Geschichte. Zur nationalen Geschichtskultur Ungarns im europäischen Kontext (1860-1948), München 2003

R. Koshar, From Monuments to Traces. Artifacts of German Memory, 1870-1990, Berkeley 2000

D. Kováč, 30. Október 1918 a jeho muži, w: Muži Deklarácie, Bratislava 2000, s. 7-21

A. Kovács-Bertrand, Der ungarische Revisionismus nach dem Ersten Weltkrieg. Der publizistische Kampf gegen den Friedensvertrag von Trianon (1918-1931), München 1997

P. Kudlak, Dyskusja wokół 11 listopada w prasie międzywojennej, Warszawa 2017, mps pracy magisterskiej pod kier. prof. dr. hab. W. Borodzieja, Instytut Historyczny Uniwersytetu Warszawskiego

I. Livezeanu, Cultural Politics in Greater Romania. Regionalism, Nation Building and Ethnic Struggle, 1918-1930, Ithaca 2000

M. Łopata, Groby żydowskich żotnierzy Wielkiej Wojny w Galicji, w: Znaki pamięci. Materiały z konferencji naukowej, Gorlice, 27.10.2007 r., red. M. Dziedziak, Gorlice 2008, s. 5-26

P.M. Majewski, „Niemcy sudeccy” 1848-1948. Historia pewnego nacjonalizmu, Warszawa 2007

T.G. Masaryk, Die Weltrevolution. Erinnerungen und Betrachtungen 1914-1918, Berlin 1925

G. Mazur, Życie polityczne polskiego Lwowa 1918-1939, Kraków 2007

C. Mick, The Dead and the Living. War Veterans and Memorial Culture in Interwar Polish Galicia, w: Sacrifice and Rebirth. The Legacy of the Last Habsburg War, red. M. Cornwall, J.P. Newman, Oxford 2016, s. 233-257

J.P. Newman, Yugoslavia in the Shadow of War. Veterans and the Limits of State Building, 1903-1945, Cambridge 2015

B.K. Nykiel, Vom Vergessen zu einer neuen kollektiven Erinnerung. Gegenwart und Vergangenheit westgalizischer Soldatenfriedhöfe, w: Schlachtfeld Galizien, red. C. Reichl-Ham, I. Nöbauer, W. Fröhlich, Wien 2016, s. 207-247 
J. Pałosz, The Military Cemetery as a Form of the Cult of the Fallen Soldier. The History of the Idea and Its Destruction on the Example of Austro-Hungarian Cemeteries in „Russian Poland”, „Remembrance and Solidarity" 2, 2014, s. 299-325

J. Piłsudski, Pisma zbiorowe, t. 8, red. K. Świtalski, Warszawa 1937

Polskie dokumenty dyplomatyczne, styczeń-maj 1919 r., red. S. Dębski, Warszawa 2017

A. Pukszto, Między stołecznościa a partykularyzmem. Wielonarodowościowe społeczeństwo Wilna w latach 1915-1920, Toruń 2006

J. Rusin, Legenda Traugutta i jubileusze. Wybrane przykłady, „Prace Naukowe Akademii im. Jana Długosza w Częstochowie. Filologia Polska. Historia i Teoria Literatury” 13, 2013

K. Ruszała, „Requiem aeternam”. Groby Galicjan poległych w I wojnie światowej na terenie dzisiejszej Słowenii, w: W Galicji i nad Soczą. Polacy i Stoweńcy na frontach I wojny światowej, red. A. Cetnarowicz, D. Nećak, S. Pijaj, B. Todorović, Kraków 2016, s. 93-104

K. Ruszała, „Żotnierze cesarza odeszli na spoczynek”. Zachodniogalicyjskie cmentarze wojenne i pochówki Słoweńców z armii austro-węgierskiej, w: W Galicji i nad Soczą. Polacy i Słoweńcy na frontach I wojny światowej, red. A. Cetnarowicz, D. Nećak, S. Pijaj, B. Todorović, Kraków 2016, s. $105-116$

F. Soukup, 28. Říjen. Předpoklady a vývoj našeho odboje domácího v československé resoluci za statní samostatnost národa, Praha 1928

P. Steinbach, Pamięć - upamiętnianie - polityka historyczna, w: Polsko-niemieckie miejsca pamięci, t. 4: Refleksje metodologiczne, red. R. Traba, H.H. Hahn, współpr. M. Górny, K. Kończal, Warszawa 2013, s. 282-304

G. Swain, Politicising Commemoration in Twentieth-century Latvia, w: Aftermath. Legacies and Memories of War in Europe, 1918-1945-1989, red. N. Martin, T. Haughton, P. Purseigle, Farnham 2014, s. 41-60

J. Szczepański, Organizacje kombatanckie i paramilitarne na Mazowszu Północnym w okresie międzywojennym, „Zeszyty Naukowe Ostrołęckiego Towarzystwa Naukowego” 23, 2009, s. 31-43

Święto Niepodległości - tradycja a współczesność, red. A. Stawarz, Warszawa 2003

C. Tacke, Denkmal im sozialen Raum. Nationale Symbole in Deutschland und Frankreich im 19. Jahrhundert, Göttingen 1995

J. Tazbir, Warszawskie pomniki narodowej chwały $i$ - hańby, w: Warszawa. O czym mówia pomniki $i$ kamienie, red. K. Mórawski, A. Stawarz, Warszawa 2000, s. 13-28

B. Varga, The Monumental Nation. Magyar Nationalism and Symbolic Politics in fin-de-siècle Hungary, New York-Oxford 2016

B. Wachowska, Od 11 listopada do 11 listopada czyli spory o symboliczne Święto Niepodległości Polski, „Acta Universitatis Lodziensis. Folia Historica” 54, 1995, s. 4-16

Die Weltkriege als symbolische Bezugspunkte. Polen, die Tschechoslowakei und Deutschland nach dem Ersten und Zweiten Weltkrieg, red. N. Stegmann, Praha 2009

K. Wessely, Theater und Gedächtnis. Der 4. März und T.G. Masaryk als Gedächtnisorte?, w: Aufbruch und Krise. Das östliche Europa und die Deutschen nach dem Ersten Weltkrieg, red. B. Störtköhl, J. Stüben, T. Weger, München 2010, s. 185-196

J. Winnicki, Rada Regencyjna Królestwa Polskiego i jej organy 1917-1918, Wrocław 2007

W. Witos, Moje wspomnienia, oprac. A. Czubiński, Z. Hammerling, S. Lato, W. Stankiewicz, Warszawa 1981

M. Zeidler, Ideas on Territorial Revision in Hungary, 1920-1945, tłum. T.J. DeKornfeld, H.D. DeKornfeld, Wayne (NY) 2007

Zjednoczenie Polskich Stowarzyszeń w Rzeczypospolitej. Sprawozdanie z działalności jego od początku istnienia do roku 1924, Warszawa 1924

L. Zugaj, Dzieje Jastkowa i okolic. Od zarania do 1939 roku, Lublin 2010 


\section{Signs of independence. 11 November Day in Poland and its counterparts in interwar Central and Eastern Europe}

The article presents policies of memory pursued in the interwar period by selected states of Central and Eastern Europe. In each of the analysed cases the choice of a symbolic date of regaining of independence or of unification became the subject of a political dispute. Contestation of such state holidays, whether for the reason of personal outlooks or patriotic ones, was not a rare phenomenon, just like their quiet boycott. Similar controversies could be observed in other fields of the policy of memory. The author describe successive phases of the replacement of "imperial" monuments with "national" ones after 1918 (and related conflicts), and ways of commemoration of the killed both in the Great War and in fights for independence and the state borders. In interwar Central and Eastern Europe even private and semi-private commemorations (tomb monuments) became the subject of political dispute, for they invariably commemorated only some of the fallen. Official monuments, dedicated to fighters of victorious matter, remained alien to the families of victims of the imperial war and advocates of national movements of the nations who did not gained independence after 1916 (as, for example, the veterans of the West Ukrainian People's Republic or supporters of Croatian independence). In some cases, symbolical tombs of unknown soldiers served not only to commemorate the killed, but also served to symbolically assert the official rule over the territory inhabited by a national minority.

Włodzimierz Borodziej - profesor w Instytucie Historycznym Uniwersytetu Warszawskiego, historyk XX w., redaktor naczelny Polskich dokumentów dyplomatycznych, przewodniczący rad naukowych Imre Kertész Kolleg w Jenie i Domu Historii Europejskiej w Brukseli. E-mail: w.borodziej@uw.edu.pl

Maciej Górny - dr hab., profesor w Instytucie Historii im. Tadeusza Manteuffla PAN w Warszawie, pracownik naukowy Niemieckiego Instytutu Historycznego w Warszawie. Redaktor naczelny „Acta Poloniae Historica”. E-mail: jmgorny@gmail.com

Piotr Tadeusz Kwiatkowski - socjolog, obecnie profesor w Instytucie Nauk Społecznych Uniwersytetu SWPS w Warszawie, wykłada też w Akademii Pedagogiki Specjalnej im. Marii Grzegorzewskiej. E-mail: pkwiatkowski@aps.edu.pl 